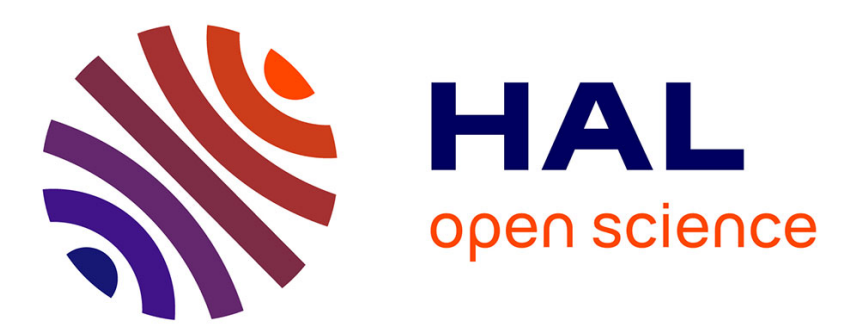

\title{
Assessing the Employment Effects of the German Welfare Reform - An Integrated CGE-Microsimulation Approach
}

Wolfgang Franz, Nicole Guertzgen, Stefanie Schubert, Markus Clauss

\section{- To cite this version:}

Wolfgang Franz, Nicole Guertzgen, Stefanie Schubert, Markus Clauss. Assessing the Employment Effects of the German Welfare Reform - An Integrated CGE-Microsimulation Approach. Applied Economics, 2011, pp.1. 10.1080/00036846.2011.564149 . hal-00708539

\section{HAL Id: hal-00708539 \\ https://hal.science/hal-00708539}

Submitted on 15 Jun 2012

HAL is a multi-disciplinary open access archive for the deposit and dissemination of scientific research documents, whether they are published or not. The documents may come from teaching and research institutions in France or abroad, or from public or private research centers.
L'archive ouverte pluridisciplinaire HAL, est destinée au dépôt et à la diffusion de documents scientifiques de niveau recherche, publiés ou non, émanant des établissements d'enseignement et de recherche français ou étrangers, des laboratoires publics ou privés. 


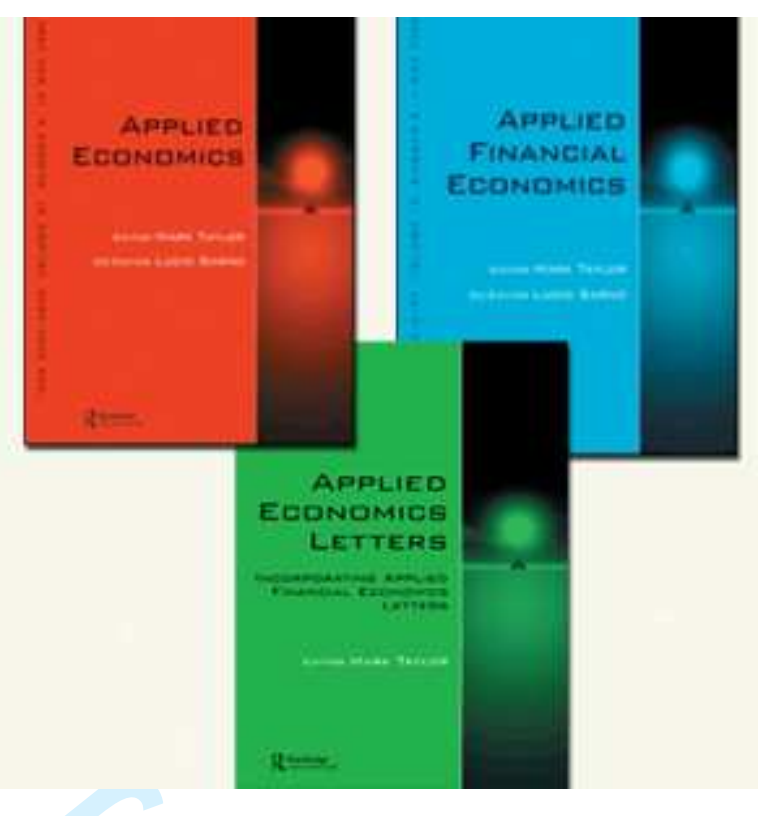

\section{Assessing the Employment Effects of the German Welfare Reform - An Integrated CGE-Microsimulation Approach}

\begin{tabular}{|r|l|}
\hline Journal: & Applied Economics \\
\hline Manuscript ID: & APE-2009-0614 \\
\hline Journal Selection: & Applied Economics \\
\hline Author: & 28-Sep-2009 \\
\hline Complete List of Authors: & $\begin{array}{l}\text { Franz, Wolfgang; Centre for European Economic Research } \\
\text { Guertzgen, Nicole; ZEW, Labour Markets } \\
\text { Schubert, Stefanie; Otto Beisheim School of Management, Chair of } \\
\text { Organization Theory } \\
\text { Clauss, Markus; Centre for European Economic Research, Labour } \\
\text { Markets }\end{array}$ \\
\hline \hline JEL Code: & $\begin{array}{l}\text { D58 - Computable and Other Applied General Equilibrium Models }< \\
\text { D5 - General Equilibrium and Disequilibrium < D - Microeconomics, } \\
\text { H31 - Household < H3 - Fiscal Policies and Behavior of Economic } \\
\text { Agents < H - Public Economics, J22 - Time Allocation and Labor } \\
\text { Supply < J2 - Time Allocation, Work Behavior, and Employment } \\
\text { Determination/Creation < J - Labor and Demographic Economics, } \\
\text { J51 - Trade Unions: Objectives, Structure, and Effects < J5 - } \\
\text { Labor-Management Relations, Trade Unions, and Collective } \\
\text { Bargaining < J - Labor and Demographic Economics }\end{array}$ \\
\hline Keywords: & \begin{tabular}{l} 
Microsimulation, CGE-Modelling, Labour Supply, Trade Unions \\
\hline
\end{tabular} \\
\hline
\end{tabular}




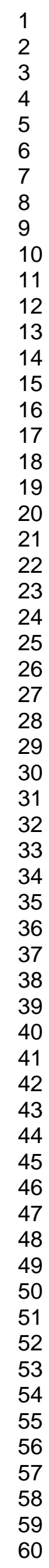

\section{5) ScholarONE"}




\title{
Assessing the Employment Effects of the German Welfare Reform - An Integrated CGE-Microsimulation Approach
}

\author{
Wolfgang Franz ${ }^{1}$, Nicole Guertzgen ${ }^{1}$, Stefanie Schubert ${ }^{1,2}$, Markus Clauss ${ }^{1}$ \\ ${ }^{1}$ Centre for European Economic Research, Mannheim \\ ${ }^{2}$ Otto-Beisheim School of Management, Vallendar
}

September 2009

\begin{abstract}
The purpose of the present paper is to quantify the employment effects of the recent German welfare reform. The key element of this reform was to merge the coexisting transfer systems social assistance and unemployment assistance into one unified benefit (Arbeitslosengeld II - ALG II). We also consider a second reform scenario that is intended to further improve the labour supply incentives of low-skilled workers. Our methodogical contribution is to use an integrated CGE-microsimulation model. In adopting such an approach, we are able to combine the advantages of microsimulation studies by accounting for the large amount of heterogeneity in terms of households' preferences and budget contraints with the advantages of an applied general equilibrium model. The latter permits us to identify potential general equilibrium repercussions through changes in wages and unemployment. The simulations indicate that the introduction of ALG II results in a negligible increase in employment of only 45,000 individuals. In contrast, a cut in benefit levels combined with a decrease in transfer withdrawal is shown to produce somewhat larger employment effects of about 190,000 individuals.
\end{abstract}

Keywords: Microsimulation, CGE-Modelling, Labour Supply

JEL-Code: H31, D58, J22

Acknowledgements: We thank the participants of the 37th Economic Seminar in Ottobeuren and especially Clemens Fuest for helpful comments on an earlier version of this paper. 


\section{Introduction}

In recent decades, the German economy has experienced a substantial increase in unemployment among low-skilled workers. In 2004, the unemployment rate among individuals with no formal vocational qualifications was 22 per cent in western Germany and about 52 per cent in eastern Germany (IAB 2007). Against this background, the German welfare system, comprising the means-tested benefits of social assistance and unemployment assistance, has been a target of frequent criticism for hindering the integration of the low-skilled unemployed into the labour market. The rationale underlying this criticism is that generous benefit levels and high transfer withdrawal rates are widely perceived as creating substantial labour supply disincentives, particularly for those with low earnings perspectives. These discouraging effects have led economists and politicians to advocate programmes intended to improve work incentives. On January 1st 2005, the German welfare system was fundamentally reformed by the "Fourth Law for Modern Services in the Labour Market", commonly referred to as the "Hartz IV" reform. A key element of this reform was to merge the coexisting transfer systems of social assistance and unemployment assistance into one unified benefit known as "Unemployment benefit II" (Arbeitslosengeld II - ALG II). Regular unemployment insurance benefits were not immediately affected by this legislation. While the reform partly entailed a significant cut in benefits - especially for those formerly entitled to unemployment assistance - high transfer withdrawal rates remained largely unchanged.

The purpose of the present paper is to quantify the employment effects associated with this recent welfare reform. Using an integrated CGE-microsimulation approach, we study two scenarios: the ALG II scenario which illustrates the effects of the new legislation and a second reform scenario that is meant to further improve the labour supply incentives for low-skilled workers. In recent years, microsimulation models have become an increasingly popular way of quantifying the employment effects of labour market reforms in the low-wage sector (e.g., Buslei and Steiner 1999, Bonin et al. 2003, Bargain and Orsini 2005, Immervoll et al. 2007, Haan and Steiner 2008). Such simulations are typically based on the estimation of a discrete choice labour supply model, in which households make decisions about their labour supply choosing from a finite set of working-time categories (van Soest 1995). Microsimulations based upon discrete choice models not only allow for a straightforward distinction between labour supply effects along the extensive and intensive margin but additionally facilitate the representation of complex tax-transfer reg- 
ulations since the latter have to be calculated for a finite set of hours only. The key advantage of such models therefore is that they allow researchers to account for the large amount of heterogeneity in terms of households' preferences and budget constraints. Nonetheless, when relying on microsimulation studies, researchers face further important challenges in obtaining a credible ex-ante assessment of the expected employment effects. One obvious drawback of microsimulation models is that they remain confined to labour supply effects and usually neglect a reform's impact on labour demand and wage determination. It is very difficult to ignore such effects, however, when a reform concerns a large number of people. In this case, participation and labour supply responses may be expected to affect the labour market equilibrium through the adjustment of wages and unemployment as well as the need to balance the public budget, which in turn gives rise to feedback effects on labour supply. General equilibrium feedback effects are especially relevant in our case, since the reforms considered here affect a large number of individuals directly and a considerable number of individuals indirectly, e.g. by altering the breakeven points, i.e. the threshold income at which individuals are no longer eligible for benefits.

To account for potential general equilibrium repercussions, the present paper adopts an integrated micro-macro approach. The model we use provides a linkage between a computable general equilibrium model and a microsimulation model, which represents a further development of the CGE model PACE-L (Böhringer et al. 2005, Boeters et al. 2005, 2006, Arntz et al. 2006, 2008). The CGE model incorporates important institutional features of the German labour market, such as sectoral wage-bargaining between unions and employers' associations, as well as sectoral labour-demand decisions. Compared with standard microsimulation models, such an integrated model therefore enables us to simulate not only labour supply effects but also the employment and wage effects resulting from our reform scenarios.

The remainder of the paper is structured as follows: Section 2 provides a description of the German welfare system before and after the introduction of ALG II. Given the remaining labour supply disincentives, we present a second reform scenario that is intended to improve participation incentives. Section 3 outlines the main methodological approach and provides a description of the integrated CGEmicrosimulation model. Section 4 presents the simulation results of the employment effects following the introduction of ALG II and our reform scenario. The final Section 5 concludes. 


\section{The German Basic Welfare System}

As of 1 January 2005, social assistance and unemployment assistance were abolished and both elements of these previous systems merged to create 'unemployment benefit II' (ALG II). The regular "unemployment benefit", which is paid for a maximum of 32 months, provided the requirements are met, has not been affected by the ALG II reform. In the next sections, we provide some institutional background information and illustrate the key labour supply disincentives associated with these transfers.

\subsection{Social Assistance}

Social assistance (SA) was a means-tested transfer programme that was targeted at people for whom the other transfer systems, such as unemployment benefits and unemployment assistance, did not provide sufficient income support. In particular, eligibility for SA payments required that income from other sources fell short of some specified basic minimum income level. As a result, households receiving transfer payments from other sources were also eligible for supplementary SA if those transfers were smaller than the specified minimum income. While SA recipients were allowed to retain a small fraction of earned labour incomes, income from other sources was deducted in full. SA payments established a minimum income that consisted of a basic rate ("Regelsatz") for the head of the household and age-dependent rates for each additional household member as well as a housing allowance for rent and heating costs. The monthly basic rates for the head of the household was 296 $€$, on average, in western Germany and $283 €$ in eastern Germany, respectively. ${ }^{1}$

\subsection{Unemployment Assistance}

Unemployment assistance (UA) was available to those unemployed claimants who had exhausted their unemployment insurance benefits. Contrary to unemployment insurance benefits, unemployment assistance required a means-test of household income and wealth and was usually paid for an unlimited period of time. The replacement ratio was 53 per cent of insured labour earnings or, alternatively, 57

\footnotetext{
${ }^{1}$ For children up to 7 years the basic rate amounted to 50 per cent of the standard basic rate (for single parents 55 per cent), for children from 7 to 14 years the fraction was 65 per cent, and for children from 14 up to 18 years 90 per cent. (Married) partners have been granted 80 per cent of the standard rate.
} 
per cent, if children were present. UA recipients whose benefits fell short of the SA minimum income were entitled to supplementary social assistance.

\section{$2.3 \quad$ ALG II}

When the "Fourth Law for Modern Services in the Labour Market" came into effect on 1 January 2005, social assistance and unemployment assistance were replaced by 'unemployment benefit II' (ALG II) as a unified welfare system targeted towards employable individuals. ${ }^{2}$ A key element of the introduction of ALG II is that benefits are no longer tied to former labour earnings as was the case with unemployment assistance. Instead, the design of ALG II largely followed the set-up of the former social assistance system providing a basic rate as well as housing and heating costs. Compared with the former SA minimum income, the basic rate under ALG II has been slightly increased: for example, for western (eastern) Germany the rate was $345 €(331 €)$ in 2005 . This increase arises from the fact that SA benefits for specific needs which were formerly granted on a discretionary basis have been replaced by a flat amount. Partners and children older than 14 years receive 80 per cent of the basic rate, while children up to 14 receive 60 per cent. The rules for earnings allowances are fairly similar to the former social assistance regulations (see Section 2.4.2 below). However, an important difference is that ALG II has a more generous wealth test. ${ }^{3}$

\subsection{Labour Supply Disincentives}

The German social assistance and unemployment assistance system has been widely criticised for creating labour supply disincentives for two reasons: First, the gap between the potential labour earnings of a transfer recipient and the minimum income level is usually considered too small. The major reason is that the skill-level of recipients is typically low, which considerably reduces their earnings perspectives in the labour market. ${ }^{4}$ Second, recipients generally face high effective marginal tax rates as a result of the tapering of benefits. In the next sections, we illustrate the disincentive effects arising from the narrow gap between transfers and potential labour

\footnotetext{
${ }^{2}$ The precise legal definition of "employability" requires persons being capable of working at least three hours a day.

${ }^{3}$ For more details on the wealth test, see e.g. Arntz et al. (2007).

${ }^{4}$ For example, in 2004 around 30 per cent of all UA and SA recipients had no formal vocational qualifications. Source: Own calculations SOEP 2004.
} 
earnings and high transfer withdrawal rates. Moreover, we examine the extent to which the introduction of ALG II may have contributed to improving the incentives to participate in the labour market.

\subsubsection{Wage-Assistance Differentials}

To illustrate the narrow gap between potential labour earnings and benefits, Table 1 displays wage-assistance differentials for different household types. This differential measures the amount by which potential disposable labour income (column (3)) exceeds the respective minimum incomes (column (1) and (2)) in percentage terms. The calculations are performed on the basis of a full-time job of 38 hours per week in the low-wage sector. ${ }^{5}$ For couples, only one of the partners is assumed to work in the low-wage sector while the spouse receives no labour or transfer income. The differentials reported in columns (4) of Table 1 reveal that the gap between disposable labour income and SA income ranged between 6.8 and about 76 per cent. Moreover, the differential generally decreased with the number of children. Single parents and couples with more than two children exhibited a differential of less than 10 per cent. This was primarily caused by the fact that average basic SA rates for children exceeded child benefits available to those individuals who were not entitled to SA payments. Column (2) shows the minimum income under ALG II, column (5) the respective differentials. The figures show that the introduction of ALG II has led to a slight decrease in the wage-assistance differential which mainly arises from replacing one-time payments by flat amounts. ${ }^{6}$ Taken together, Table 1 suggests that both the SA and the ALG II minimum income levels create considerable labour supply disincentives, particularly for low-income workers with children.

\subsubsection{Transfer Withdrawal}

According to the unemployment assistance regulations, additional labour earnings exceeding an exemption of 20 per cent of the benefit level - but no less than 165 $€$ - were entirely taxed away. Further, people working for 15 hours or longer a week were no longer eligible for unemployment assistance. The solid budget line in the upper panel of Figure 1 shows the relationship between gross labour earnings and disposable income for a single person without children. To illustrate the

\footnotetext{
${ }^{5}$ For the threshold in the low-wage sector, we assume a gross hourly wage of $2 / 3$ of the median of the wage distribution. This corresponds to an hourly wage of $8.50 €$.

${ }^{6}$ Later on, in the simulations, one-time payments are accounted for by adding a constant rate of 18 per cent to the basic social assistance rates.
} 
Table 1: Wage-assistance differentials SA and ALG II

\begin{tabular}{|c|c|c|c|c|c|}
\hline \multirow[b]{2}{*}{ Household type } & \multicolumn{2}{|c|}{ Min. income in $€$} & \multirow{2}{*}{$\begin{array}{c}\text { Disposable } \\
\text { income } \\
\text { in } € \\
(3)\end{array}$} & \multicolumn{2}{|c|}{ Differential } \\
\hline & $\begin{array}{l}\text { SA } \\
\text { (1) }\end{array}$ & $\begin{array}{c}\text { ALG II } \\
(2)\end{array}$ & & $\begin{array}{l}\text { in } \% \\
\text { SA } \\
(4)\end{array}$ & $\begin{array}{c}\text { in } \% \\
\text { ALG II } \\
\text { (5) }\end{array}$ \\
\hline Single households & & & & & \\
\hline No children & 583,34 & 625,85 & 1029,44 & 76,47 & 64,49 \\
\hline One child & 872,70 & 1009,67 & 1264,08 & 44,85 & 25,20 \\
\hline Two children & 1126,48 & 1281,03 & 1520,20 & 34,95 & 18,67 \\
\hline Three ore more children & 1454,50 & 1636,62 & 1587,54 & 9,15 & $-3,00$ \\
\hline Couple households & & & & & \\
\hline No children & 910,78 & 1019,49 & 1135,55 & 24,68 & 11,38 \\
\hline One child & 1151,44 & 1302,29 & 1340,06 & 16,38 & 2,90 \\
\hline Two children & 1447,64 & 1601,99 & 1616,85 & 11,69 & 0,93 \\
\hline Three ore more children & 1680,60 & 1992,20 & 1794,97 & 6,81 & $-9,90$ \\
\hline
\end{tabular}

The minimum income level consists of the basic rates, additional needs as well as average rent and heating costs. The calculation of disposable income is performed on the basis of a gross hourly wage of $8.50 €$, a 38 hours full time job held by the head of the household and accounts for housing and child benefits. SOEP 2004, own calculations.

disincentives for recipients with relatively high former earnings, who currently face low earnings perspectives, we assume a former net earnings level of $1,900 €$ and a potential gross hourly wage of $8.50 €$. The budget line shows that in this case the incentive to take up a job required a gross monthly income of at least 1,500 $€$. Figure 1 thus demonstrates that the design of unemployment assistance created substantial disincentives for those individuals with relatively high former earnings who experienced a large human capital depreciation.

Under the means-tested social assistance regime, eligibility was contingent on recipients' inability to cover their needs from their own income or wealth. Thus, similar to unemployment assistance, SA benefits were subject to large transfer withdrawal rates of up to 100 per cent. More specifically, labour earnings which exceeded an exempted 25 per cent of the basic rate were withdrawn at a rate of 85 per cent. The maximum exemption amounted to 50 per cent of the basic rate. The solid line in the lower panel of Figure 1 shows the budget line for a (potential) single SA recipient without children. ${ }^{7}$ For this household type, the breakeven point, i.e. the point at which individuals were no longer eligible for assistance, was reached at gross earnings of about $1,000 €$.

\footnotetext{
${ }^{7}$ The calculation of the standard rate assumes a monthly gross rent of $216 €$. Further, in the figure one-time payments are accounted for by adding a constant rate of 18 per cent to the basic social assistance rate.
} 
Figure 1: Disposable Income of a Single Person with no Children

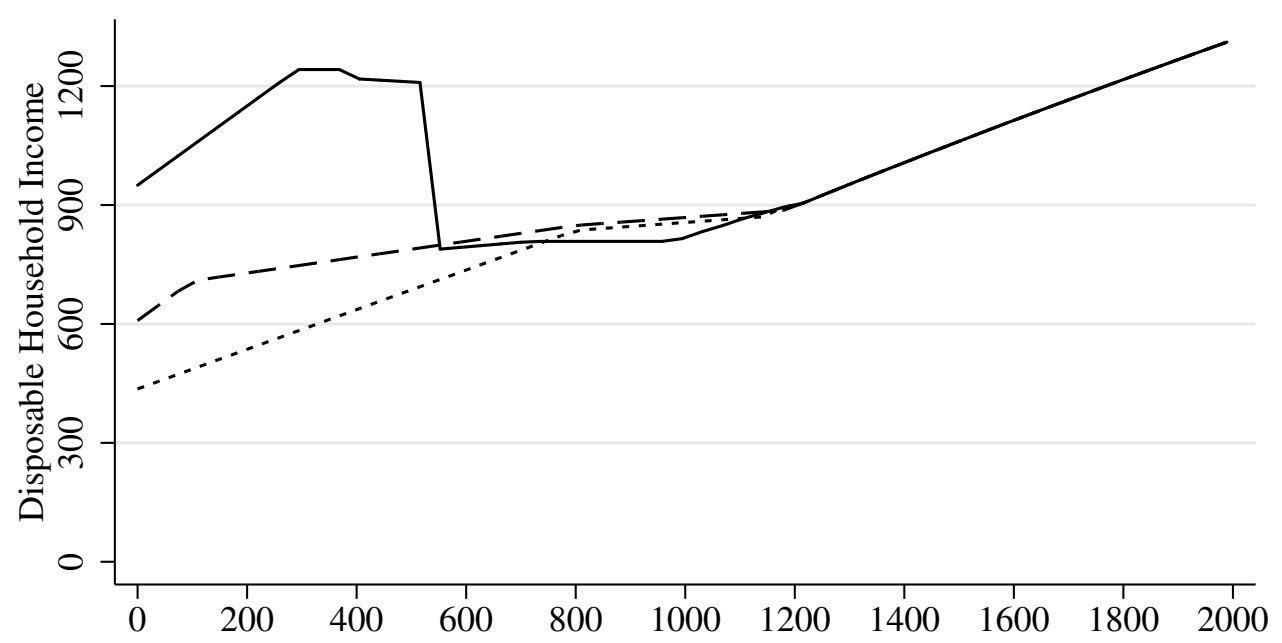

Gross Monthly Earnings in Euro

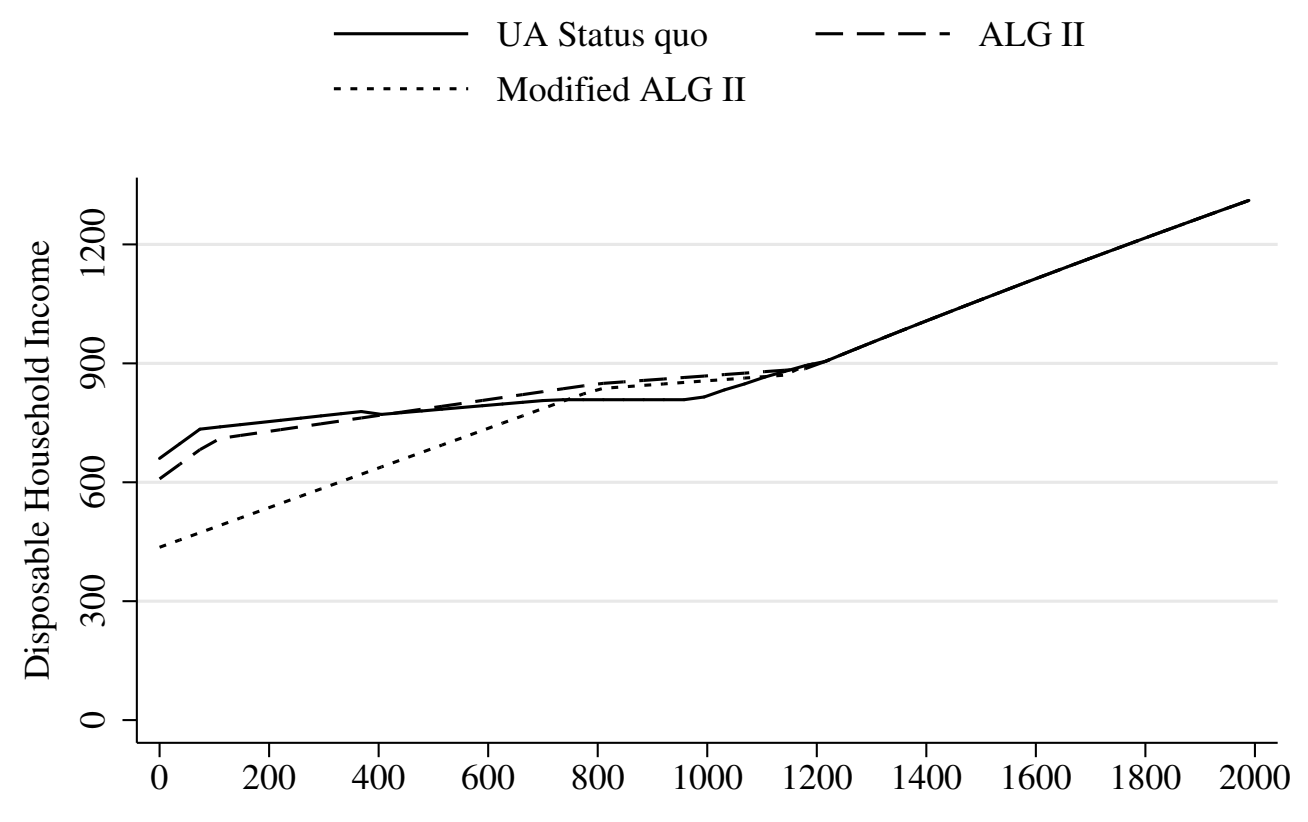

Gross Monthly Earnings in Euro

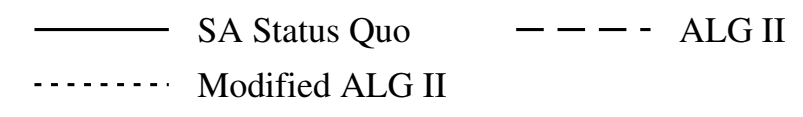


In sum, the two graphs demonstrate that both systems discouraged labour supply over a wide range of gross labour earnings particularly for those persons with a very low income potential.

The dashed lines in Figure 1 represent the introduction of ALG II. Gross earnings exceeding an exemption of about $100 €$ are taxed away at a rate of 80 per cent up to a threshold level of $800 €$ and at a rate of 90 per cent between 800 and 1,200 $€$ gross labour earnings (for households with children up to $1,500 €$ ). Figure 1 thus demonstrates that transfer withdrawal regulations under ALG II led only to a slight increase in the participation incentives for former SA recipients. Further, it can be seen that the breakeven point has been raised. For former recipients of unemployment assistance, in contrast, the upper panel of Figure 1 shows that the ALG II regulations led to a substantial increase in the incentives to take up a part time job since the large discontinuity in the budget curve owing to the 15-hours regulation has been removed.

\subsection{Modified ALG II}

The second scenario basically follows several reform proposals that have been advocated in the recent political discussion in Germany (e.g., German Council of Economic Experts 2006). The common features of these proposals consist in the reduction of marginal tax rates in the lower income ranges associated with a decrease in the minimum income guarantee. Starting from the introduction of ALG II, our second scenario therefore aims at widening the gap between benefits and potential labour earnings and at reducing transfer withdrawal rates. More specifically, basic rates for household heads and their partners are cut by 50 per cent. Such a strong reduction in benefit levels immediately raises the question as to how the reform can be reconciled with the current constitutional welfare state principle. In legal terms, any decrease in benefit levels ought to be defendable if ALG II recipients are able to sustain their present level of income support, either by taking up employment in the primary labour market with supplementary ALG II, or by being assigned to a so-called "working opportunity". The functioning and the various types of these opportunities are discussed elsewhere (German Council of Economic Experts 2006). In our simulations, we assume - for the sake of simplicity - that such opportunities can be provided in a cost-neutral manner. As the reform is generally targeted 
at employable persons, certain groups of individuals are excluded from our reform scenario. ${ }^{8}$ Further, the basic exemption is abolished and transfer withdrawal rates are reduced to 50 per cent for all households which are subject to the cut in benefit levels. ${ }^{9}$ The dotted lines in Figure 1 depict the relationship between gross earnings and disposable income for this modified ALG II scenario. The budget lines show that the reform entails a sizeable income effect not only for former recipients of unemployment assistance but also for former SA beneficiaries. Moreover, the budget lines show that for both groups the reform is likely to increase the incentive to take up a part time job.

\section{The Microsimulation-CGE Model}

\subsection{Microsimulation Model}

\subsubsection{Data and Household Types}

The microsimulation model is based on individual household data taken from the German Socio-Economic Panel Study G-SOEP, a representative household survey for Germany. The data refer to the benchmark year 2004, with social assistance and unemployment assistance constituting the prevailing welfare system. The microsimulation model covers all households with flexible time allocation and observable hours of work. Pensioners, students, women on maternity leave, civil servants and the self-employed are assumed to be inflexible and are excluded from our simulations, since they are not expected to change their labour supply behavior in response to the reforms considered here. Accounting for single and couple households, this results in four different household types: flexible singles, flexible couples, "mixed" couples consisting of a flexible and an inflexible spouse and, finally, one household type comprising all those households which include only inflexible members. This latter household type is not considered in our simulations. Moreover, the labour supply of further household members is assumed to be constant.

\footnotetext{
${ }^{8}$ These include, for example, single parents, households with children younger than 14 years and individuals with a reduced earning capacity.

${ }^{9}$ For singles without children (with children), the reduced transfer withdrawal rate applies up to a threshold of $800 €(1,000 €)$. Gross labour earnings exceeding this amount are taxed away at a rate of 90 per cent up to an amount of $1,600(1,800) €$. For couples without children (with children), we impose a similar reduction in transfer withdrawal up to a threshold of $1,200 €(1,600$ $€)$. Labour earnings in excess of this amount are taxed away at a rate of 90 per cent rate up to earnings of $1,600(2,000) €$
} 


\subsubsection{Discrete Choice Model of Labour Supply}

Following van Soest (1995), we use a discrete choice model of labour supply in which each individual chooses from a finite set of working-time categories: Underlying our simulations is a set of five working-time categories for singles $(0,15,30,38$, or 47 hours per week), which results in 25 working hours combinations for couple households. Such a discrete choice approach has the advantage of allowing for a straightforward distinction between labour supply effects along the extensive and intensive margin. Moreover, it provides a more realistic description of labour supply options as we do not generally observe infinitesimal changes of working hours but rather a concentration of hours at particular working hours categories.

At the heart of the discrete choice approach is the assumption that a single household chooses the working-time category which maximises its individual utility. Similarly, a couple household chooses the labour supply combination maximising a joint utility function. Underlying this assumption is the so-called unitary approach of household behaviour (see Blundell and MaCurdy 1999). Choosing the zero-hours option is viewed as reflecting voluntary unemployment. Households' preferences are represented by a translog utility function $U$ of household $j$ depending on the number of hours $h_{k}$ in category $k$. The category combination $(k, l)$ represents the choice of couples with the woman selecting $h_{k}^{f}$ and the man choosing $h_{l}^{m}$ hours of work:

$$
U_{j}\left(x_{j k}\right)=x_{j k}^{\prime} \cdot A \cdot x_{j k}+\beta_{j}^{\prime} \cdot x_{j k} .
$$

The argument vector $x_{j k}$ of the utility function includes the logs of disposable household income $y_{j k}$ and weekly hours of leisure for men $m$ and women $f$, respectively,

$$
x_{j k}=\left(\log \left(y_{j}\left(h_{j k}^{f}, h_{j l}^{m}\right)\right), \log \left(T-h_{j k}^{f}\right), \log \left(T-h_{j l}^{m}\right)\right)
$$

where $T$ denotes the time endowment which is taken to amount to 80 hours a week. $A$ is a $3 \times 3$-matrix containing the coefficients of the quadratic terms, while $\beta_{j}^{\prime}$ represents the coefficients of the linear terms. Extending the utility function by an error term, the parameters in equation (1) can be estimated using a conditional multinomial logit model. The error term is assumed to be independently standard extreme-value distributed. According to the seminal contribution of McFadden (1974), the probability for singles (couples) of preferring option $k$ (combination $(k, l))^{10}$ over all other options $m \neq k$ is given by the following expression:

\footnotetext{
${ }^{10}$ In what follows, hours categories and hours-combination categories are used synonymously.
} 


$$
P\left(U_{j k}>U_{j m}\right)=\frac{\exp \left(U_{j}\left(x_{j k}\right)\right)}{\sum_{l} \exp \left(U_{j}\left(x_{j l}\right)\right)}, m \neq k
$$

The maximum likelihood estimation results based upon actual labour supply and disposable incomes in 2004 can be found in Appendix A1-A4. ${ }^{11}$ The parameters include interactions between leisure, income and a set of household characteristics. These interactions account for differences in the preferences of households for certain hours of work options. In addition, constant terms are included to capture fixed costs of working.

\subsubsection{The Budget Constraint}

In addition to the labour supply module, the microsimulation model contains a tax-benefit calculator, which provides a detailed representation of the German taxtransfer system. As mentioned earlier, a key advantage of the discrete choice set-up is that it considerably facilitates the incorporation of complex tax-transfer regulations since the latter are to be calculated for a finite set of hours only. In the context of our discrete choice set-up, the budget constraint needs to be determined for all hours categories in the status quo year 2004 and the reform scenarios described in Section 2.4.2 and 2.5. To obtain disposable incomes, each household's gross earnings are derived from multiplying individual gross hourly wages with hours. Since gross hourly wages are unobservable for those who are not employed, wages have to be estimated using a Mincer-type wage regression with education, experience and some further controls (e.g. nationality, marital status). We use Heckman's (1979) selectivity correction to account for the positive selection of employed individuals for whom wages are observed. Other sources of income, such as income from rents, are added to labour earnings. Net monthly incomes are calculated by deducting income taxes and social security contributions from gross monthly incomes according to the German tax system. Finally, disposable monthly incomes are obtained by adding transfer payments. When determining the entitlement to social assistance, unemployment assistance and ALG II, we further attempt to account for household wealth. A detailed description of the German tax-transfer system is given in Appendix A.2. Later, for the policy simulations, we use a first-order approximation of the tax-transfer system. This is done by disturbing the calculations of disposable

\footnotetext{
${ }^{11}$ Individual labour supply observed in the data is matched to the working-hour categories used in our model as follows: $0<h<22.5$ : 15 hours, 22.5 $\leq h<34: 30$ hours, 34 $\leq h<42.5: 38$ hours, and $h \geq 42.5: 47$ hours.
} 
income marginally at all relevant points to calculate numerically the local effective marginal burden of the total tax-transfer system.

\subsubsection{Simulation Method}

Given the individual parameters of the utility functions and expected disposable incomes for the pre and post-reform situation, we can proceed to simulate labour supply effects. In this regard, there are different simulation mechanisms that have been proposed in the literature. A first possibility is to use the probabilities predicted by the conditional logit model in order to calculate each household's expected working hours in the pre and post-reform situation. The disadvantage with this procedure is that it is not possible to calculate transition probabilities conditional on status quo labour supply. As we are particularly interested in the labour supply responses of those individuals who do not participate in the benchmark, we opt for the method proposed by Duncan and Weeks (1998) (see also Creedy and Kalb 2005). The Duncan-Weeks simulation method exploits the fact that we have information about the choices of the households in the initial situation. This information can be used to transform the utility evaluations of the disposable incomes into conditional probabilities. To do so, we take independent random draws from an extreme-value distribution, which are added to the deterministic part of the utility function (1). We retain only those random numbers that maximise pre-reform utility at the observed working hours. For each household, we retain 100 random numbers for each working hours category (or combination). Doing so, we end up with households choosing exactly one option with a probability of one in the benchmark. Given the post-reform disposable income change, we then recalculate the new utility maximising choice for each realisation of the error terms yielding a genuine probability distribution over all working-time categories.

\subsection{The CGE-Module}

The CGE-module is based on an applied static general equilibrium model. The general equilibrium approach allows for a quantification of direct and indirect effects arising from our policy measures. The distinctive feature of our model is the detailed modeling of the German labour market comprising sector-specific bargaining between trade unions and employers' associations. The model distinguishes between 
low and high-skilled labour. In each of the seven sectors, a representative firm produces a homogeneous output. Within a nested constant-elasticity-of-substitution (CES) production structure, each firm determines its optimal demand for intermediate and value added inputs. Value added inputs consist of low-skilled labour and a composite of high-skilled labour and capital, the HK-aggregate. This reflects the empirical evidence that low-skilled labour is a relatively good substitute for the HKaggregate whereas capital and high-skilled labour are relatively poor substitutes for each other. In what follows, we only briefly sketch the main components of the CGE model which are most relevant to our analysis. A more detailed algebraic model presentation including a description of the calibration as well as subsequent developments of the model can be found in Böhringer et al. (2005), Boeters (2005, 2006) as well as Arntz et al. (2006, 2008).

\subsubsection{Labour Demand}

Firms minimise costs at each production nest. The cost functions of the value added aggregate $c_{v a, s}$ and the HK-aggregate $c_{h k, s}$ for each sector $s$ can be written as:

$$
\begin{aligned}
& c_{v a, s}=\left[\beta_{s}^{L}\left(\frac{w_{L, s} \cdot\left(1+t_{l, s, L}\right)}{\bar{w}_{L, s} \cdot\left(1+\bar{t}_{l, s, L}\right)}\right)^{1-\sigma_{s}^{L}}+\left(1-\beta_{s}^{L}\right) c_{h k, s}^{1-\sigma_{s}^{L}}\right]^{\frac{1}{1-\sigma_{s}^{L}}} \\
& c_{h k, s}=\left[\beta_{s}^{H}\left(\frac{w_{H, s} \cdot\left(1+t_{l, s, H}\right)}{\bar{w}_{H, s} \cdot\left(1+\bar{t}_{l, s, H}\right)}\right)^{1-\sigma_{s}^{H}}+\left(1-\beta_{s}^{H}\right)\left(\frac{r\left(1+t_{k, s}\right)}{\bar{r}\left(1+\bar{t}_{k, s}\right)}\right)^{1-\sigma_{s}^{H}}\right]^{\frac{1}{1-\sigma_{s}^{H}}},
\end{aligned}
$$

where $\beta_{s}^{L}$ und $\beta_{s}^{H}$ denote initial cost shares for low-skilled labour $L$ within the value added aggregate and for high-skilled labour $H$ within the HK-aggregate, respectively. $\sigma_{s}^{L}$ and $\sigma_{s}^{H}$ are elasticities of substitution for the value added and HKaggregate. $w_{L, s} \cdot\left(1+t_{l, s, L}\right)$ and $w_{H, s} \cdot\left(1+t_{l, s, H}\right)$ represent the employer's labour costs including wage-related costs per hour for each skill type. $r\left(1+t_{k, s}\right)$ stands for the gross price of capital. Variables with a bar refer to the benchmark situation. This yields the following demand functions for low-skilled labour $L_{L, s}$ and high-skilled labour $L_{H, s}$ at the sectoral level $s$ depending on the output level $Y_{s}$ :

$$
\begin{aligned}
L_{L, s} & =Y_{s}\left(c_{v a, s} \cdot \frac{\bar{w}_{L, s} \cdot\left(1+\bar{t}_{l, s, L}\right)}{w_{L, s} \cdot\left(1+t_{l, s, L}\right)}\right)^{\sigma_{s}^{L}} \\
L_{H, s} & =Y_{s}\left(\frac{c_{v a, s}}{c_{h k, s}}\right)^{\sigma_{s}^{L}}\left(c_{h k, s} \cdot \frac{\bar{w}_{H, s} \cdot\left(1+\bar{t}_{l, s, H}\right)}{w_{H, s} \cdot\left(1+t_{l, s, H}\right)}\right)^{\sigma_{s}^{H}} .
\end{aligned}
$$




\subsubsection{Wage Determination and Labour Market Equilibrium}

In each sector, an employer's association and a trade union bargain over wages according to the "right-to-manage" approach: parties bargain over wages, and firms decide on labour demand taking the bargained wage as given (see e.g. Oswald 1985). The bargaining outcome results from the maximisation of a Nash function $\Omega_{s}$ that includes the objective functions of both parties and their respective fallback options. The objective function of the employer is given by its profit $\pi_{s}$, while the fallback option implies zero profits:

$$
\ln \Omega_{s}=\ln \pi_{s}+\rho_{H, s} \ln \Gamma_{H, s}+\rho_{L, s} \ln \Gamma_{L, s} .
$$

$\rho_{r, s}$ denotes bargaining power of both skill types $r=L, H$ relative to the firm's bargaining power. For each skill type, the union's objective function $\Gamma_{r, s}$ is employment $L_{r, s}$ times the value of a job $V_{r, s}$ minus the value of unemployment $V_{U, r}$ :

$$
\Gamma_{r, s}=L_{r, s}\left(V_{r, s}-V_{U, r}\right)
$$

Following the literature on search unemployment (e.g. Pissarides 1990), the values of the labour market states are recursively determined as weighted averages of the incomes in the case of employment and unemployment, where the weights are computed from the transition probabilities between the labour market states. ${ }^{12}$ More specifically, the value of a job $V_{r, s, t}$ in period $t$ can be expressed as:

$$
V_{r, s, t}=\frac{1}{1+r}\left[I_{r, s}\left(1+n p c_{r, s}\right)+\left(1-\mu_{r, s}\right) V_{r, s, t+1}+\mu_{r, s} V_{U, r, t+1}\right]
$$

$\mu_{r, s}$ represents the sector-specific separation rate from employment to unemployment, $n p c_{r, s}$ is a non-pecuniary pay component ${ }^{13}$ and $I_{r, s}$ is the average disposable income of an employed worker. Under the steady-state assumption, the value of employment equals its value in the previous period. Thus, we can replace the difference between the value of employment and unemployment in equation (8) by:

$$
V_{r, s}-V_{U, r}=\left[\frac{I_{r, s}\left(1+n p c_{r, s}\right)-r V_{U, r}}{r+\mu_{r, s}}\right]
$$

\footnotetext{
${ }^{12}$ The transition probabilities from employment to unemployment result from the sector-specific separation rates and sectoral unemployment rates. While the separation rates are obtained from the IABS-Employment Subsample, the latter are calibrated within the model.

${ }^{13}$ Given the initial wage differentials, the non-pecuniary components are calibrated so as to render unemployed individuals indifferent between employment in the different sectors.
} 
The value of unemployment $V_{U, r}$ is assumed to be exogenously given. Trade unions take a utilitarian perspective with respect to individuals and labour supply options. In other words, an employed individual's average disposable income and the value of unemployment are calculated as weighted averages in case of employment and unemployment for all individuals and labour supply options, respectively. ${ }^{14}$ In turn, the wage that results from bargaining in general equilibrium is used to derive the income positions of all households in employment. To calculate disposable incomes, we use the numerically approximated values of the marginal effective tax rates (see Section 3.1.3).

A reform of the tax-transfer system has two important implications for wage determination: First, the reforms affect the effective marginal tax rates either through an explicit change in tax rates or through lower transfer withdrawal rates. Trade unions account for these skill-specific marginal tax rates in the negotiations. Apriori, the net effect is not clear because the marginal burden increases for some individuals while it decreases for others. Koskela and Vilmunen (1996) show in this context that with a constant average tax rate, an increase in the effective marginal tax rate raises the degree of tax progression, which leads to wage moderation on behalf of unions. Second, a cut in benefits reduces the expected income when unemployed and, thus, the value of the fall-back position of unions. For given labour demand, this effect is further accentuated if the probability of becoming unemployed is raised due to increased labour market participation.

Outcomes of these sector-specific negotiations are the wages for low and highskilled individuals. Firms determine their optimal labour demand according to equation (5) and (6), taking the bargained wages as given. Unions anticipate firms' labour demand decisions, which influences the outcome indirectly. The difference between labour supply and demand endogenously determines unemployment. Individuals are mobile among sectors. In equilibrium, job-seekers must be indifferent between any

\footnotetext{
${ }^{14}$ For couple households, the average disposable income of an employed individual is calculated as a weighted expected value, taking into account different labour market states "employed" $(e)$ and "unemployed" $(n)$ of the spouse. The disposable income for positive labour supply options is linked to the labour market status ,employed“ $(e)$. In contrast, for individuals who are ,involuntarily unemployed" $(n)$ we assign the disposable income for zero hours labour supply, which is strongly determined by the German transfer system - irrespective of the actual labour supply decision. As weights for the different labour market states, we use the probabilities $P_{e, j}=\left(1-u_{r}\right)$ und $P_{n, j}=u_{r}$, where $u_{r}$ represents the household-type specific unemployment rate. In our model, we distinguish 42 household types (see Table A1). For these categories we calibrate householdspecific unemployment rates by splitting non-working individuals into voluntarily and involuntarily unemployed persons so as to match the skill-specific unemployment rates in the benchmark.
} 
two of the sectors.

\subsubsection{Budget Neutrality}

The scenarios are modeled as budget neutral reforms by fixing the budget $T$ in real terms according to the benchmark level. Government revenues consist of taxes on capital $K_{s}$, labour, consumption $C_{z}$ of commodity $z$, output $Y_{s}$ and profits $\pi_{s}$ :

$$
T=\sum_{s} t_{k, s} r K_{s}+T_{M S}+\sum_{z} t_{c, z} p_{c, z} C_{z}+\sum_{s} t_{y, s} p_{y, s} Y_{s}+\sum_{s} t_{\pi} \pi_{s}
$$

where $t_{k, s}$ is the capital tax rate, $t_{c, z}$ the consumption tax rate, $t_{y, s}$ the output tax rate, and $t_{\pi}$ the profit tax rate. $r, w_{i, s}, p_{c, z}$ and $p_{y, s}$ denote the respective prices. All other taxes paid by firms, e.g. trade taxes, are subsumed under the profit tax. $T_{M S}$ is the balance of labour income taxes plus social security contributions minus transfer payments to those households captured by the microsimulation module. The income tax contains a proportional adjustment parameter that is used for balancing the public budget in the counterfactual policy simulations. According to our comprehensive income tax, this refers to the tax rates $t_{k, s}, t_{\pi}$ and taxes on labour that are included in $T_{M S}$.

\subsection{Linking the Microsimulation and CGE-Modules}

The labour supply module and the CGE module are kept separate and iterated until we arrive at a global solution. ${ }^{15}$ Using the labour supply module, we first derive the labour supply reactions of our policy measures. Given the partial equilibrium nature of this analysis, wages and unemployment rates are held constant. The resulting labour supply is aggregated (by skill type) and transferred to the CGE model. Running the CGE model, we derive wage reactions and changes in the unemployment rate resulting from the change in labour supply. The changes in wages and income taxes required to balance the public budget are fed back to the labour supply module for the next iteration, where the next round's labour supply effects are computed. This proceeds until the two modules converge. ${ }^{16}$

\footnotetext{
${ }^{15}$ In the literature, this procedure is usually referred to as an iterative "bottom-up-top-down" approach (for a taxonomy see e.g. Peichl (2008)).

${ }^{16}$ The convergence criterion is the change in the unemployment rates: if the change in unemployment rates between two subsequent iterations of less than $10 \mathrm{e}-5$, the solution is found.
} 
Transferring data from the labour supply module to the CGE module requires the aggregation of individual labour supply per skill type. To do so, labour supply in hours is weighted by the respective wage rate of the benchmark yielding skill-specific labour supply in efficiency units. We assume that the individual wages move in proportion to the average macroeconomic wage of the respective skill group. When transferring data from the CGE module to the labour supply module, it is therefore first necessary to adjust individual wages and, second, to account for the change in the income tax rate, which is used to balance the government's budget in the CGE module.

\section{Results}

For both reform scenarios we first discuss the partial equilibrium labour supply reactions, i.e. with constant wages and without imposing revenue neutrality. We then turn to the general equilibrium effects taking into account the wage responses, the labour demand reactions and the budget balancing through an adjustment of the marginal income tax.

\subsection{Partial Equilibrium ALG II}

Table 2 displays the transition probabilities into the different working hours categories conditional on status quo labour supply. When simulating labour supply effects, it has to be kept in mind that the introduction of ALG II not only directly impacts the labour supply behaviour of former beneficiaries of social assistance and unemployment assistance but also entails indirect effects by generating new entitlement among those not previously eligible for benefits. ${ }^{17}$ To distinguish direct and indirect effects, Panel A and B refer to those individuals who were previously entitled to benefits, whereas Panel $\mathrm{C}$ contains the transition matrix for those not eligible in the benchmark.

The figures in the first row of Panel A show that our model predicts slight positive participation effects for former potential SA recipients not participating in the status quo. In contrast, former SA beneficiaries working 15 hours reduce labour

\footnotetext{
${ }^{17} \mathrm{~A}$ further reason for additional eligibility is the more generous wealth test under ALG II than under the SA regulations. The reform conferred entitlement to ALG II benefits on people whose private assets previously excluded them by law from receiving SA and who were not eligible for unemployment assistance (see also Clauss and Schnabel 2009).
} 
market participation. Potential SA recipients who work full time and overtime in the benchmark are virtually unaffected in their labour supply behaviour. This is not surprising as the optimality of such a labour supply decision reflects a locally low marginal rate of substitution between consumption and leisure, thereby requiring large shifts in the budget curve in order to induce individuals to change their labour supply. Finally, a comparison of the marginal distributions of the working hours categories shows that the reform results in an overall increase in the participation rate of about 1.6 percentage points. Given the total predicted number of about 1.8 million potential SA recipients in the benchmark, ${ }^{18}$ this corresponds to an increase in labour supply of about 29,863 individuals in this group. Panel B reports the

Table 2: Transitions into working hours categories ALG II

\begin{tabular}{|c|c|c|c|c|c|c|}
\hline Status quo (SQ) & \multicolumn{6}{|c|}{ Scenario } \\
\hline A. SA & \multicolumn{6}{|c|}{ ALG II } \\
\hline beneficiaries & 0 & 15 & 30 & 38 & 47 & Distribution SQ \\
\hline 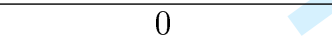 & 97.5 & 0.7 & 0.4 & 1.3 & 0.1 & 69.1 \\
\hline 15 & 0.6 & 98.4 & 0.5 & 0.5 & 0.0 & 13.3 \\
\hline 30 & 0.0 & 0.0 & 99.6 & 0.3 & 0.0 & 6.9 \\
\hline 38 & 0.0 & 0.0 & 0.0 & 99.9 & 0.1 & 4.3 \\
\hline 47 & 0.0 & 0.0 & 0.0 & 0.0 & 100 & 6.4 \\
\hline Distribution ALG II & 67.5 & 13.5 & 7.2 & 5.3 & 6.5 & 100.0 \\
\hline B. UA & \multicolumn{6}{|c|}{ ALG II } \\
\hline beneficiaries & 0 & 15 & 30 & 38 & 47 & Distribution SQ \\
\hline 0 & 91.8 & 2.3 & 0.9 & 4.2 & 0.8 & 100.0 \\
\hline Distribution ALG II & 91.8 & 2.3 & 0.9 & 4.2 & 0.8 & 100.0 \\
\hline C. Non-eligible & \multicolumn{6}{|c|}{ ALG II } \\
\hline individuals & 0 & 15 & 30 & 38 & 47 & Distribution SQ \\
\hline 0 & 99.4 & 0.4 & 0.1 & 0.1 & 0.0 & 16.3 \\
\hline 15 & 2.1 & 97.6 & 0.1 & 0.2 & 0.0 & 12.0 \\
\hline 30 & 2.1 & 0.6 & 97.2 & 0.1 & 0.0 & 9.2 \\
\hline 38 & 1.0 & 0.6 & 0.1 & 98.2 & 0.0 & 50.2 \\
\hline 47 & 0.5 & 0.6 & 0.1 & 0.3 & 98.5 & 12.3 \\
\hline Distribution ALG II & 17.3 & 12.2 & 9.0 & 49.4 & 12.1 & 100.0 \\
\hline
\end{tabular}

Transition probabilities (per cent) into different working hours categories conditional on status quo labour supply choice.

results for former UA beneficiaries. Given our choice of working time categories this

\footnotetext{
${ }^{18}$ This calculation is based upon all flexible individuals between 15 and 65 years in our sample. According to the official statistics of the Federal Statistical Office in Germany there were 1.6 million SA employable recipients in 2004 (i.e., excluding those who were ill, disabled or in education). Therefore, our model overpredicts the number of beneficiaries which is presumably mainly due to non take-up which we do not model here.
} 
group is restricted to work zero hours in the benchmark, as employed individuals working at least 15 hours were no longer eligible for unemployment assistance. A comparison of the marginal distributions of the working hours categories shows that the reform results in an overall increase in the participation rate of about 8.2 percentage points. Given the total predicted number of about 1.8 million formerly UA recipients, ${ }^{19}$ this translates into an increase in labour supply of about 148,773 individuals in this group. Taking into account that both groups partly overlap due to some additionally participating UA recipients receiving supplementary SA $(9,844$ persons), this results in an overall additional labour supply of 168,792 individuals.

Panel C refers to those individuals who were neither eligible for SA nor for UA. Here we observe negative participation effects. Comparing the marginal distributions of working hours reveals that our simulations predict a reduction in participation of about 1 percentage point, corresponding to 228,354 individuals who withdraw from the labour market. The figures in the first column reveal that the fraction of those who reduce participation is largest among those non-eligible individuals holding a part time job in the benchmark. This result may partly be attributed to the extension of eligibility to higher net earnings, which induces some individuals to reduce their labour supply in order to become entitled to supplementary benefits. For couple households this creates particular incentives for women to give up a part time job thereby explaining the relatively larger participation reduction among part time working individuals. Moreover, closer inspection of the off-diagonal entries shows that formerly non-eligible individuals not only reduce participation but also working-time, which is consistent with the induced incentives to reduce labour supply.

Table 3 presents the effects on participation rates, average working time and total labour supply for a number of sub-aggregates of individuals. In row (1) we display the change in participation rates in percentage points, row (2) reports the change in average working time in per cent, whereas row (3) and (4) contain the change in labour supply measured in hours (3) and in persons (4).

The last column in row (1) indicates that overall participation decreases slightly by about 0.2 percentage points. Moreover, the figures show that the responses vary greatly across skill groups. In particular, the decrease in participation is more pronounced among high-skilled individuals than among their low-skilled counterparts.

\footnotetext{
${ }^{19}$ This calculation is based upon all flexible individuals between 15 and 65 years in our sample. According to the official statistics of the Employment Agency (BA) in Germany there were 2.26 million UA recipients in 2004.
} 
Table 3: Labour supply effects ALG II

\begin{tabular}{lrrrrrr}
\hline \hline \multirow{1}{c}{ Change } & \multicolumn{2}{c}{ Couples } & Singles & \multicolumn{2}{c}{ Qualification } & \multirow{2}{*}{ All } \\
& Men & Women & & Low & High & \\
\hline (1) Participation rate (in \%-points) & 0.084 & -0.467 & -0.209 & -0.029 & -0.248 & -0.215 \\
(2) Average working time (in per cent) & -0.292 & -0.247 & -0.626 & -0.606 & -0.302 & -0.339 \\
(3) Labour supply in hours (in per cent) & -0.208 & -0.975 & -0.892 & -0.652 & -0.616 & -0.620 \\
(4) Labour supply in persons & & & & $-1,204$ & $-58,359$ & $-59,563$ \\
\hline \hline
\end{tabular}

The reason is that the latter are disproportionately represented among former transfer beneficiaries who exhibit positive participation effects. Further, women in couples feature the largest reduction in participation rates. Average working time decreases for all individual groups, giving rise to unambiguous negative effects on labour supply in hours. The overall decrease in participation translates into a reduced labour supply of about 59,563 persons, 98 per cent of which belong to the high-skilled. ${ }^{20}$

\subsection{General Equilibrium ALG II}

In this section, we turn to the general equilibrium effects following the introduction of ALG II. In addition to the labour supply effects discussed in Section 4.1, we thus account for wage and labour demand reactions as well as the adjustment of the marginal income tax rate to balance the public budget.

Table 4 shows that the reform causes low-skilled wages to decrease by 0.74 per cent, while gross hourly wages of the high-skilled slightly increase by 0.16 per cent. The fact that the reform exerts downward pressure on low-skilled wages while leaving high-skilled wages virtually unchanged can be explained by the following mechanisms. First, the reform entails an increase in the average marginal effective tax burden (row (8)) and a reduction in benefit levels which generally leads to wage moderation on behalf of unions. Moreover, the effect on the fallback utility turns out to be larger the greater the probability of becoming unemployed. The skill-specific changes in marginal effective tax rates displayed in row (8) along with a larger status quo unemployment for the low-skilled indicate that both effects are more relevant for this skill group. In sum, this induces a larger downward pressure on low-skilled

\footnotetext{
${ }^{20}$ Using the same microsimulation model, Clauss and Schnabel (2008) obtain a reduction in labour supply of about $-12,000$ persons. The different results can be traced back to their simulation method. While our simulations are based upon calibrated transition probabilities, Clauss and Schnabel (2008) use the predicted choice probabilities of the conditional logit model.
} 
Table 4: General equilibrium labour supply and employment effects ALG II

\begin{tabular}{lrrrrrr}
\hline \hline \multicolumn{1}{c}{ Change } & \multicolumn{2}{c}{ Couples } & \multicolumn{3}{c}{ Singles } & \multicolumn{3}{c}{ Qualification } & All \\
& Men & Women & & Low & High & \\
\hline (1) Participation rate (in \%-points) & 0.024 & -0.540 & -0.263 & -0.199 & -0.292 & -0.278 \\
(2) Average working time (in per cent) & -0.312 & -0.298 & -0.682 & -0.693 & -0.333 & -0.375 \\
(3) Labour supply in hours (in per cent) & -0.294 & -1.141 & -1.015 & -1.014 & -0.703 & -0.738 \\
(4) Labour supply (in persons) & & & & $-8,396$ & $-68,688$ & $-77,084$ \\
(5) Employment (hours, in per cent) & & & & 0.337 & -0.173 & -0.130 \\
(6) Employment (persons, in per cent) & & & & 1.229 & 0.114 & 0.233 \\
(7) Employment (in persons) & & & & 25,111 & 19,556 & 44,667 \\
(8) Gross wages (in per cent) & & & & -0.740 & 0.155 & \\
(9) Unemployment rate (in \%-points) & & & -1.219 & -0.447 & \\
(10) Av. effective marginal tax rate (\%-points) & & & & & & \\
\hline
\end{tabular}

wages. Second, there is a countervailing effect on wages since a decrease in labour market participation tends to reduce unemployment rates and, therefore, raises fallback utilities and wages. For high-skilled individuals this countervailing effect on wages dominates and even causes wages even to increase somewhat, as the decrease in participation is relatively more pronounced among this skill group. With respect to the general equilibrium labour supply responses, the figures in row (1) and (4) indicate negative participation effects which are of a similar magnitude but slightly larger than those in Table 3. The reinforcing negative effect on participation is more pronounced among the low-skilled due to the reform's negative impact on low-skilled wages. Further, the wage reduction for the low-skilled translates into an increase in labour demand by 0.34 per cent, as measured by the increase in hours of employment (row (5)). For the high-skilled, in contrast, labour demand in hours is reduced by 0.17 per cent. Despite this decrease, the employment response at the extensive margin is found to be positive for both groups (rows (6) and (7)), which is due to the reduction in working time among those participating in the labour market (row (2)). Along with the decrease in participation this translates into a 1.22 percentage point reduction of the unemployment rate for the low-skilled and a 0.45 percentage point reduction for the high-skilled (row (9)).

\subsection{Partial Equilibrium Modified ALG II}

Table 5 displays the transition probabilities into the different working hours categories for the modified ALG II scenario (M-ALG II). When interpreting the figures, it is helpful to place the results in Table 5 alongside the figures in Table 2 . In partic- 
ular, a comparison of Panel A and B in Table 2 and 5 shows that the differences in the participation effects are mainly driven by the labour supply responses of former potential transfer recipients.

Table 5: Transitions into working hours categories M-ALG II

\begin{tabular}{|c|c|c|c|c|c|c|}
\hline Status quo (SQ) & \multicolumn{6}{|c|}{ Scenario } \\
\hline A. SA & \multicolumn{6}{|c|}{ M-ALG II } \\
\hline beneficiaries & 0 & 15 & 30 & 38 & 47 & Distribution SQ \\
\hline 0 & 92.8 & 1.5 & 1.3 & 3.9 & 0.5 & 69.1 \\
\hline 15 & 2.1 & 93.9 & 1.2 & 2.3 & 0.6 & 13.3 \\
\hline 30 & 0.0 & 0.0 & 99.7 & 0.3 & 0.0 & 6.9 \\
\hline 38 & 0.1 & 0.1 & 0.1 & 99.7 & 0.1 & 4.3 \\
\hline 47 & 0.0 & 0.0 & 0.0 & 0.2 & 99.7 & 6.4 \\
\hline Distribution ALG II & 64.4 & 13.5 & 8.0 & 7.3 & 6.8 & 100.0 \\
\hline B. UA & \multicolumn{6}{|c|}{ M-ALG II } \\
\hline beneficiaries & 0 & 15 & 30 & 38 & 47 & Distribution SQ \\
\hline 0 & 87.1 & 3.5 & 1.5 & 6.6 & 1.3 & 100.0 \\
\hline Distribution M-ALG II & 87.1 & 3.5 & 1.5 & 6.6 & 1.3 & 100.0 \\
\hline C. Non-eligible & \multicolumn{6}{|c|}{ M-ALG II } \\
\hline individuals & 0 & 15 & 30 & 38 & 47 & Distribution SQ \\
\hline 0 & 99.3 & 0.3 & 0.2 & 0.2 & 0.0 & 16.3 \\
\hline 15 & 2.1 & 97.5 & 0.2 & 0.2 & 0.0 & 12.0 \\
\hline 30 & 1.9 & 0.8 & 97.1 & 0.2 & 0.0 & 9.2 \\
\hline 38 & 1.0 & 0.9 & 0.1 & 97.9 & 0.0 & 50.2 \\
\hline 47 & 0.5 & 0.7 & 0.1 & 0.9 & 97.8 & 12.3 \\
\hline Distribution M-ALG II & 17.2 & 12.3 & 9.1 & 49.4 & 12.0 & 100.0 \\
\hline
\end{tabular}

Transition probabilities (per cent) into different working hours categories conditional on status quo labour supply choice.

While the participation rate of former SA beneficiaries is raised by 4.7 percentage points, the increase amounts to 12.9 percentage points for former UA beneficiaries. Due to the stronger benefit reduction and the more generous transfer withdrawal regulations the positive participation effects are therefore much larger than in the ALG II scenario. A comparison of Panel C in Table 2 and 5 shows that the decrease in participation among non-eligible individuals is of a similar magnitude as that following the introduction of ALG II. Overall, the increase in participation among former beneficiaries corresponds to an additional labour supply of 269,911 persons, while the decrease among formerly non-eligible individuals results in 211,711 individuals withdrawing from the labour market.

The last column in row (1) in Table 6 shows that the overall increase in participation is about 0.2 percentage points. Among the displayed subaggregates, the only 
individual group featuring a decrease in participation is that of women in couple households. This result is driven by women who react to the increased labour supply of formerly non-working spouses by reducing own labour market participation. Moreover, the figures show that, similar to the introduction of ALG II, positive participation reactions are typically stronger among low-skilled individuals as compared to their high-skilled counterparts. Average working time is found to decrease

Table 6: Labour supply effects M-ALG II

\begin{tabular}{lrrrrrr}
\hline \hline \multirow{2}{c}{ Change } & \multicolumn{2}{c}{ Couples } & \multicolumn{3}{c}{ Singles } & \multicolumn{2}{c}{ Qualification } & All \\
& Men & Women & & \multicolumn{1}{c}{ Low } & \multicolumn{1}{c}{ High } & \\
\hline (1) Participation rate (in \%-points) & 0.183 & -0.289 & 0.919 & 0.609 & 0.138 & 0.210 \\
(2) Average working time (in per cent) & -0.510 & -0.283 & -0.839 & -0.609 & -0.481 & -0.503 \\
(3) Labour supply in hours (in per cent) & -0.311 & -0.734 & 0.326 & 0.374 & -0.307 & -0.229 \\
(4) Labour supply in persons & & & & 25,718 & 32,482 & 58,200 \\
\hline \hline
\end{tabular}

for all individual groups. Compared with the introduction of ALG II the decrease is even more pronounced as part time employment becomes considerably more attractive due to the more generous transfer withdrawal regulations. The last column in row (3) shows that the reduction in average working time results in a negative labour supply reaction along the intensive margin, i.e. labour supply measured in hours decreases even though the labour supply reaction along the extensive margin is found to be positive.

\subsection{General Equilibrium Modified ALG II}

Turning to the general equilibrium effects, the figures in row (6) in Table 7 show that the reform exerts downward pressure on both low and high-skilled wages, which are predicted to decrease by 1.7 per cent and 0.4 per cent, respectively. Underlying these relatively larger wage reductions compared with the ALG II scenario are the following mechanisms. A first explanation is that our second scenario entails a more pronounced increase in the average marginal tax burden of 3.8 percentage points for the low-skilled and 2.1 percentage points for the high-skilled (row (8)), respectively. A second reason is that, due to the larger reduction in benefit levels, the modified ALG II leads to a considerably larger reduction in the fallback utility of unions. The figures in row (1) and (4) show that compared with the partial equilibrium results in general equilibrium the positive participation responses are mitigated for both skill groups, giving rise to an overall increase in labour supply of 20,189 persons. The 
wage reductions for both skill groups lead to an increase in labour demand. From row (5) it can be seen that the increase in hours of employment turns out to be more procounced for the low-skilled due to their larger wage reduction and their larger labour demand elasticities. Owing to the reduction in working time, the employment response at the extensive margin is again found to be larger for both skill groups (rows (6) and (7)). Along with the decrease in labour supply, the figures in row (9) show that unemployment rates decrease for both skill groups. The increase in employment at the extensive margin results in 58,208 low-skilled and 131,597 highskilled individuals who are additionally employed after the reform. Note that the employment gain of high-skilled individuals exceeds that of low-skilled individuals in absolute terms as high-skilled labour represents a considerably larger fraction of our relevant population. In sum, the overall employment gain of 189,806 persons is found to be considerably larger than in the ALG II scenario. Taken together, when comparing our general equilibrium analysis with the partial equilibrium results, our simulations suggest that the employment effects of any reform are likely to be considerably understated unless potential wage adjustments and the resulting changes in unemployment rates are accounted for.

Table 7: General equilibrium labour supply and employment effects M-ALG II

\begin{tabular}{|c|c|c|c|c|c|c|}
\hline \multirow[b]{2}{*}{ Change } & \multicolumn{2}{|c|}{ Couples } & \multirow[t]{2}{*}{ Singles } & \multicolumn{2}{|c|}{ Qualification } & \multirow[t]{2}{*}{ All } \\
\hline & Men & Women & & Low & High & \\
\hline (1) Participation rate (in \%-points) & 0.054 & -0.415 & 0.758 & 0.297 & 0.032 & 0.073 \\
\hline (2) Average working time (in per cent) & -0.572 & -0.391 & -0.936 & -0.804 & -0.552 & -0.584 \\
\hline (3) Labour supply in hours (in per cent) & -0.516 & -1.039 & 0.024 & -0.325 & -0.511 & -0.489 \\
\hline (4) Labour supply (in persons) & & & & 12,559 & 7,630 & 20,189 \\
\hline (5) Employment (hours, in per cent) & & & & 1.056 & 0.044 & 0.129 \\
\hline (6) Employment (persons, in per cent) & & & & 2.824 & 0.768 & 0.989 \\
\hline (7) Employment (in persons) & & & & 58,208 & 131,597 & 189,806 \\
\hline (8) Gross wages (in per cent) & & & & -1.680 & -0.389 & \\
\hline (9) Unemployment rate (in \%-points) & & & & -1.856 & -0.671 & \\
\hline (10) Av. effective marginal tax rate (\%-points) & & & & 3.848 & 2.076 & \\
\hline
\end{tabular}

\section{Conclusions}

The purpose of the present paper was to quantify the employment effects of the recent German welfare reform. The key element of this reform was to merge the 
coexisting transfer systems of social assistance and unemployment assistance into one unified benefit (Arbeitslosengeld II - ALG II). Given that the introduction of this unified benefit left the labour supply disincentives of the German welfare system to a large part unchanged, we also consider a second reform scenario that is intended to further encourage labour market participation of low-skilled workers.

Our methodological contribution is to use an integrated CGE-microsimulation model. In adopting such an approach, we are able to combine the advantages of microsimulation studies by accounting for the large amount of heterogeneity in terms of households' preferences and budget constraints with the advantages of an applied general equilibrium model. The latter permits us to identify potential general equilibrium repercussions through changes in wages and unemployment. Such feedback effects are especially relevant in our case, since the reforms considered here affect a large number of individuals directly and a considerable number of individuals indirectly, by generating additional entitlement to benefits.

Overall, our simulations lead us to conclude that the Hartz IV reform is unlikely to succeed in producing substantial labour supply and employment effects. In particular, the results of the partial equilibrium analysis show that potential positive participation effects of former transfer beneficiaries are likely to be dominated by negative participation effects of formerly non-eligible individuals. In sum, our simulations predict a decrease in labour supply of about 60,000 persons. The general equilibrium results indicate that due to the larger average marginal tax burden and the lower benefit level low-skilled wages decrease, whereas high-skilled wages are virtually left unchanged. Along with the decrease in participation this leads to lower unemployment rates and to an overall employment gain of about 45,000 individuals.

In contrast, the simulation results of our modified reform scenario indicate that a cut in benefit levels combined with a reduction in transfer withdrawal rates may entail considerably larger labour supply and employment effects. Yet, given that there are about 3.2 million households ("Bedarfsgemeinschaften") who are likely to be affected by the reform, the overall magnitude of the predicted employment gain of about 190,000 persons still appears to be rather modest. Similar to the introduction of ALG II, the simulations show that the comparatively modest employment gain is mainly driven by formerly non-eligible individuals. By generating additional entitlement, the reforms induce women in couples in particular to withdraw from the labour market in order to become eligible for supplementary benefits.

When comparing our general equilibrium analysis with the partial equilibrium 
microsimulation results, our simulations suggest that the employment effects of any reform are likely to be considerably understated unless potential wage adjustments and the resulting changes in unemployment rates are accounted for. Our results consequently strongly suggest the need for a model capable of simulating labour supply effects and accounting for changes in wages and unemployment in order to obtain an ex-ante assessment of the associated employment effects. 


\section{References}

[1] Arntz, Melanie, Stefan Boeters and Nicole Gürtzgen (2006): Alternative Approaches to Discrete Working Time Choice in an AGE Framework, Economic Modelling 23, 1008-1032.

[2] Arntz, Melanie, Stefan Boeters, Nicole Gürtzgen and Stefanie Schubert (2008): Analysing Welfare Reform in a Microsimulation-AGE Model - The Value of Disaggregation, Economic Modelling 25, 422-439.

[3] Arntz, Melanie, Markus Clauss, Margit Kraus, Reinhold Schnabel, Alexander Spermann and Jürgen Wiemers (2007): Arbeitsangebotseffekte und Verteilungswirkungen der Hartz-IV-Reform, IAB-Forschungsbericht, 10.

[4] Bargain, Olivier and Kristian Orsini (2005): In-Work Policies in Europe: Killing two Birds with one Stone? Labour Economics 13, 667-697.

[5] Blundell, Richard and Thomas MaCurdy (1999): Labor Supply: A Review of Alternative Approaches, in: Ashenfelter, Orley and David Card (eds.): Handbook of Labor Economics, Vol. 3, Amsterdam (Elsevier), 1559-1695.

[6] Böhringer, Christoph, Stefan Boeters and Michael Feil (2005): Taxation und Unemployment: An Applied General Equilibrium Approach for Germany, Economic Modelling 22, 81-108.

[7] Boeters, Stefan, Michael Feil and Nicole Gürtzgen (2005): Discrete Working Time Choice in an Applied General Equilibrium Model, Computational Economics 26, 183-211.

[8] Boeters, Stefan, Nicole Gürtzgen and Reinhold Schnabel (2006): Reforming Social Welfare in Germany - An Applied General Equilibrium Analysis, German Economic Review 7, 363-388.

[9] Bonin, Holger, Wolfram Kempe and Hilmar Schneider (2003): Household Labour Supply Effects of Low-Wage Subsidies in Germany, Schmollers Jahrbuch 123, 199-208.

[10] Buslei, Hermann and Viktor Steiner (1999): Beschäftigungseffekte von Lohnsubventionen im Niedriglohnbereich, Nomos, Baden-Baden. 
[11] Clauss, Markus and Reinhold Schnabel (2009): Distributional and Behavioural Effects of the German Labour Market Reform, Zeitschrift für Arbeitsmarktforschung 41, 431-446.

[12] Creedy, John and Guyonne Kalb (2005): Discrete Hours Labour Supply Modelling: Specification, Estimation and Simulation, Journal of Economic Surveys 19, 697-734.

[13] Duncan, Alan and Melvin Weeks (1998): Simulating Transitions Using Discrete Choice Models, Papers and Proceedings of the American Statistical Association $106,151-156$.

[14] German Council of Economic Experts (2006): Arbeitslosengeld II reformieren: Ein zielgerichtetes Kombilohnmodell, Expertise im Auftrag des Bundesministers für Wirtschaft und Technologie, Wiesbaden: Sachverständigenrat.

[15] Haan, Peter and Viktor Steiner (2008), Making Work Pay for the Elderly Unemployed: Evaluating Alternative Policy Reforms for Germany, FinanzArchiv $64,380-402$.

[16] Heckman, James (1979): Sample Selection Bias as a Specification Error, Econometrica, 47, 153-161.

[17] Immervoll, Herwig, Henrik J. Kleven, Claus T. Kreiner and Emmanuel Saez (2007): Welfare Reform in European Countries - A Microsimulation Analysis, Economic Journal 117, 1-44.

[18] Institut für Arbeitsmarkt- und Berufsforschung (IAB) (2007): Qualifikationsspezifische Arbeitslosigkeit im Jahr 2005 und die Einführung der Hartz-IVReform. Empirische Befunde und methodische Probleme, IAB Forschungsbericht Nr. 9/2007, Nürnberg.

[19] Koskela, Erkki and Jouko Vilmunen (1996): Tax Progression is Good for Employment in Popular Models of Trade Union Behaviour, Labour Economics 3, 65-80.

[20] McFadden, Daniel (1974): Conditional Logit Analysis of Qualitative Choice Behavior, in: P. Zarembka (Hrsg.), Frontiers in Econometrics, New York: Academic Press, 105-142. 
[21] Oswald, Andrew J. (1985): The Economic Theory of Trade Unions: An Introductory Survey, Scandinavian Journal of Economics 87, 197-233.

[22] Peichl, Andreas (2008), The Benefits of Linking CGE and Microsimulation Models: Evidence from a Flat Tax Analysis, IZA Discussion Paper 3715. Bonn. Forthcoming: Journal of Applied Economics.

[23] Pissarides, Christopher A. (1990): Equilibrium Unemployment Theory, Oxford: Basil Blackwell.

[24] van Soest, Arthur (1995): Structural Models of Family Labor Supply: A Discrete Choice Approach, Journal of Human Resources 30, 63-88. 


\section{A Appendix}

\section{A.1 Household Categories}

Table A1: Household categories

\begin{tabular}{ll}
\hline \hline Number & Definition \\
\hline 16 & Flexible couple, skill group wife $i$ and husband $j, x$ children \\
8 & Husband in mixed couple, skill group $i, x$ children \\
8 & Wife in mixed couple, skill group i, $x$ children \\
2 & Single male, skill group $i$, no children \\
2 & Single female, skill group $i$, no children \\
6 & Single, skill group $i, x$ children \\
\hline \hline
\end{tabular}

$i, j=\mathrm{L}$ (low-skilled), $\mathrm{H}$ (high-skilled), $x=0,1,2,3$ (or more) children.

Low-skilled individuals are those without any completed vocational training.

\section{A.2 Calculation of Disposable Incomes}

To calculate disposable incomes, we account for the following tax and transfer components:

Social security contributions: From gross earnings, we deduct contributions to the unemployment, health and pension insurance up to the upper social security contribution limit. For health insurance contributions, we assume the average contribution rate. Gross monthly earnings below $400 €$ are exempted from social security contributions, while gross earnings between 400 and $800 €$ are subject to a reduced contribution rate.

Income taxes: Income taxes are calculated on the basis of taxable income which is obtained by subtracting standard deductions from gross earnings. To determine income taxes we apply the 2004 German tax schedule to taxable earnings. For married couples, income tax legislation allows for marital income tax splitting. According to this method, the tax schedule is applied to half of the joint taxable income, while the resulting tax amount is doubled to obtain total income taxes.

Housing benefits: Because social assistance and ALG II already contain a housing transfer component, households who are entitled to these transfers are not eligible for housing benefits. For the remaining households we calculate the entitlement to housing benefits on the basis of rents and household income. 
Child benefits: We consider child benefits which are $154 € €$ for each child (from the fourth child onwards the benefit amounts to $179 €$ ). For those households who fare better with a child exemption we consider the latter to compute taxable earnings.

Apart from these tax and transfer components we account for further transfer and income components, such as e.g. alimonies, student transfers (BAföG), scholarships, maternity leave transfers, pensions as well as incomes from community or military services. The latter five components are only relevant for individuals with a fixed labour supply and are considered to compute the total disposable income in mixed households.

Household wealth: As our data contain only insufficient information on assets, we use information on the yearly interest incomes together with incomes from dividends to compute potential capital assets. These calculated assets serve as a basis for the wealth test.

\section{A.3 Estimation Results}

Table A2: Maximum Likelihood Estimation Results Single Men

\begin{tabular}{lrrrr}
\hline \hline & Coeff. & SE & $\mathrm{z}$ & $\mathrm{P}>\mathrm{z}$ \\
\hline Disposable Income & 10.11 & 2.71 & 3.73 & 0.00 \\
Disposable Income`2 & 0.06 & 0.04 & 1.37 & 0.17 \\
Disposable Income X Leisure & -2.41 & 0.59 & -4.10 & 0.00 \\
Leisure & 74.05 & 21.47 & 3.45 & 0.00 \\
Leisure`2 & -6.80 & 2.51 & -2.70 & 0.01 \\
Leisure X High-skilled & 1.77 & 2.16 & 0.82 & 0.41 \\
Leisure X Low-skilled & 2.36 & 2.21 & 1.07 & 0.29 \\
Leisure X East & 0.49 & 0.37 & 1.30 & 0.19 \\
Leisure X ationality & 0.75 & 0.85 & 0.88 & 0.38 \\
Leisure X Age & -0.80 & 0.47 & -1.71 & 0.09 \\
Leisure X Age^2 & 0.00 & 0.00 & 0.82 & 0.41 \\
Leisure^2 X Age & 0.09 & 0.06 & 1.64 & 0.10 \\
Leisure X Disabled & 0.95 & 0.88 & 1.07 & 0.28 \\
Dummy Full time Employment & 3.91 & 0.27 & 14.64 & 0.00 \\
\hline Observations & \multicolumn{5}{c}{3,000} \\
Log Likelihood & -669 \\
\hline \hline
\end{tabular}

Conditional Multinomial Logit with 5 working hours categories. $(0,15,30,38,49)$. SOEP 2004. 
Table A3: Maximum Likelihood Estimation Results Single Women

\begin{tabular}{|c|c|c|c|c|}
\hline & Coeff. & $\overline{\mathrm{SE}}$ & $\overline{\mathrm{z}}$ & $\overline{\mathrm{P}>\mathrm{Z}}$ \\
\hline Disposable Income & 8.27 & 2.82 & 2.93 & 0.00 \\
\hline Disposable Income^2 & 0.26 & 0.07 & 3.90 & 0.00 \\
\hline Disposable Income X Leisure & -2.36 & 0.58 & -4.08 & 0.00 \\
\hline Leisure & 87.75 & 19.86 & 4.42 & 0.00 \\
\hline Leisure $^{-}$X 2 & -8.99 & 2.37 & -3.79 & 0.00 \\
\hline Leisure X High-skilled & 1.79 & 1.31 & 1.36 & 0.17 \\
\hline Leisure X Low-skilled & 2.67 & 1.37 & 1.95 & 0.05 \\
\hline Leisure X East & -0.25 & 0.38 & -0.65 & 0.51 \\
\hline Leisure X Nationality & 1.63 & 0.61 & 2.65 & 0.01 \\
\hline Leisure X Age & 0.38 & 0.44 & 0.86 & 0.39 \\
\hline Leisure X Age^2 & 0.00 & 0.00 & 2.14 & 0.03 \\
\hline Leisure $^{\sim} 2 \mathrm{X}$ Age & -0.07 & 0.06 & -1.20 & 0.23 \\
\hline Leisure X Disabled & -0.25 & 1.40 & -0.18 & 0.86 \\
\hline Leisure X Children $<7$ & 4.13 & 0.55 & 7.47 & 0.00 \\
\hline Leisure X Children 7-16 & 1.08 & 0.25 & 4.33 & 0.00 \\
\hline Leisure X Children $>=17$ & 0.57 & 0.31 & 1.85 & 0.06 \\
\hline Dummy Full time Employment & 0.02 & 0.38 & 0.07 & 0.95 \\
\hline Dummy Part time*) Employment & -1.66 & 0.28 & -5.86 & 0.00 \\
\hline Observations & \multicolumn{4}{|c|}{3,890} \\
\hline Log Likelihood & \multicolumn{4}{|c|}{-974} \\
\hline
\end{tabular}

Conditional Multinomial Logit with 5 working hours categories $(0,15,30,38,49)$. SOEP 2004.

*) 15 or 30 hours per week 
Table A4: Maximum Likelihood Estimation Results Flexible Couples

\begin{tabular}{|c|c|c|c|c|}
\hline & Coeff. & SE & $\mathrm{z}$ & $\mathrm{P}>\mathrm{z}$ \\
\hline Disposable Income & 20.02 & 2.24 & 8.95 & 0.00 \\
\hline Dispsable Income^ 2 & 0.19 & 0.04 & 4.86 & 0.00 \\
\hline Leisure Husband X Leisure Wife & -2.88 & 0.54 & -5.33 & 0.00 \\
\hline Disposable Income X Leisure Husband & -3.26 & 0.33 & -9.94 & 0.00 \\
\hline Disposable Income X Leisure Wife & -1.63 & 0.28 & -5.73 & 0.00 \\
\hline Leisure Husband & 62.70 & 7.34 & 8.54 & 0.00 \\
\hline Leisure^2 Husband & -1.84 & 0.62 & -2.96 & 0.00 \\
\hline Leisure Husband X East & -9.32 & 2.71 & -3.44 & 0.00 \\
\hline Leisure Husband X Nationality & -0.46 & 0.42 & -1.12 & 0.27 \\
\hline Leisure Husband X Leisure Wife X East & 2.35 & 0.67 & 3.48 & 0.00 \\
\hline Leisure Husband X Leisure Wife X Nationality & -0.13 & 0.10 & -1.26 & 0.21 \\
\hline Leisure Husband X High-skilled & 2.14 & 1.30 & 1.65 & 0.10 \\
\hline Leisure Husband X Low-skilled & 2.99 & 1.32 & 2.27 & 0.02 \\
\hline Leisure Husband X Age & -0.33 & 0.09 & -3.48 & 0.00 \\
\hline Leisure Husband X Age^2 & 0.00 & 0.00 & 4.17 & 0.00 \\
\hline Leisure Husband X Disabled & 0.55 & 0.77 & 0.72 & 0.47 \\
\hline Leisure Wife & 101.12 & 7.06 & 14.33 & 0.00 \\
\hline Leisure^2 Wife & -8.74 & 0.62 & -14.06 & 0.00 \\
\hline Leisure Wife X East & -11.25 & 2.57 & -4.38 & 0.00 \\
\hline Leisure Wife X Nationality & 0.13 & 0.39 & 0.34 & 0.73 \\
\hline Leisure Wife X High-skilled & 1.76 & 0.78 & 2.27 & 0.02 \\
\hline Leisure Wife X Low-skilled & 1.95 & 0.82 & 2.39 & 0.02 \\
\hline Leisure Wife X Age & -0.35 & 0.09 & -3.68 & 0.00 \\
\hline Leisure Wife X Age^2 & 0.00 & 0.00 & 4.35 & 0.00 \\
\hline Leisure Wife X Disabled & 0.20 & 1.42 & 0.14 & 0.89 \\
\hline Dummy Full time Employment Husband & 4.96 & 0.20 & 24.88 & 0.00 \\
\hline Dummy Full time Employment Wife & 0.70 & 0.24 & 2.93 & 0.00 \\
\hline Dummy Part time*) Employment Wife $^{*}$ & -0.59 & 0.21 & -2.81 & 0.01 \\
\hline Dummy Employment Both Spouses & -0.20 & 0.18 & -1.09 & 0.28 \\
\hline Observations & \multicolumn{4}{|c|}{65,075} \\
\hline Log Likelihood & \multicolumn{4}{|c|}{$-5,867$} \\
\hline
\end{tabular}

Conditional Multinomial Logit with 25 working hours categories $(0,15,30,38,49) \times(0,15,30,38,49)$. SOEP 2004.

*) 15 or 30 hours per week. 
Table A5: Maximum Likelihood Estimation Results Mixed Couples

\begin{tabular}{lrrrr}
\hline \hline & Coeff. & SE & Z & P>Z \\
\hline Disposable Income & 1.94 & 1.61 & 1.20 & 0.23 \\
Disposable Income`2 & 0.46 & 0.07 & 6.92 & 0.00 \\
Disposable Income X Leisure & -1.39 & 0.35 & -4.00 & 0.00 \\
Leisure & 66.75 & 21.64 & 3.08 & 0.00 \\
Leisure X Household Head Female & 0.09 & 0.75 & 0.11 & 0.91 \\
Leisure`2 & -5.37 & 2.66 & -2.02 & 0.04 \\
Leisure X Leisure inflex. Spouse & -0.13 & 0.16 & -0.79 & 0.43 \\
Leisure X High-skilled X Female & 0.71 & 1.15 & 0.62 & 0.54 \\
Leisure X Low-skilled X Female & 1.73 & 1.23 & 1.41 & 0.16 \\
Leisure X High-skilled X Male & -0.79 & 1.20 & -0.66 & 0.51 \\
Leisure X Low-skilled X Male & -1.42 & 1.29 & -1.10 & 0.27 \\
Leisure X Age & -0.76 & 0.46 & -1.67 & 0.09 \\
Leisure X Age`2 & 0.01 & 0.00 & 3.56 & 0.00 \\
Leisure`2 X Age & 0.04 & 0.05 & 0.77 & 0.44 \\
Leisure X East & 1.60 & 0.65 & 2.48 & 0.01 \\
Leisure X East X Household Head Female & -3.47 & 0.71 & -4.87 & 0.00 \\
Leisure X Nationality & -1.49 & 0.56 & -2.65 & 0.01 \\
Leisure X Children < 7 years & 1.27 & 0.69 & 1.85 & 0.06 \\
Leisure X Children 7-16 years & 0.93 & 0.27 & 3.43 & 0.00 \\
Leisure X Children > =17 years & 0.49 & 0.21 & 2.29 & 0.02 \\
Leisure X Male X Disabled & 0.66 & 1.14 & 0.58 & 0.56 \\
Dummy Part time*) Employment Wife & -0.24 & 0.22 & -1.12 & 0.27 \\
Dummy Full time Employment Wife & 0.69 & 0.34 & 2.06 & 0.04 \\
Dummy Full time Employment Husband & 3.76 & 0.37 & 10.29 & 0.00 \\
Dummy Employment X Children < years & -0.41 & 0.40 & -1.04 & 0.30 \\
Dummy Employment X Children 7-16 years & 0.21 & 0.16 & 1.32 & 0.19 \\
\hline Observations & & 4,745 & \\
Log Likelihood & & $-1,215$ & \\
\hline \hline & & & & \\
\hline
\end{tabular}

Conditional Multinomial Logit with 5 working hours categories

(0, 15, 30, 38, 49). SOEP 2004.

*) 15 or 30 hours per week. 
Separate Appendix for Referees: Description of the CGE Model

\section{Equations and Variables of the Model}

PACE-L is a static general equilibrium model for an open economy covering 7 sectors. Its innovative feature is the incorporation of decentralised wage bargaining, which is modelled as a "right-to-manage" Nash-bargaining, as presented in Section 3.2.2 in the main text.

\section{$1.1 \quad$ Firms}

In each production sector, a representative firm produces a homogeneous output. We use a nested constant-elasticity-of-substitution (CES) production function to reflect empirical evidence on the substitution possibilities. Figure 1 provides a diagrammatic overview of the nesting structure.

Figure 1: Nesting structure of production function

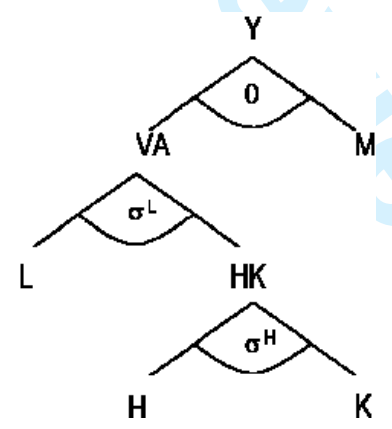

In the top nest, a material composite $(M)$ is combined in fixed proportions with aggregate value added $(V A) . M$ consists of intermediate inputs with fixed coefficients (Leontief production structure), whereas $V A$ consists of low-skilled labour $(L)$ and a composite of high-skilled labour $(H)$ and capital $(K)$, trading off at a constant elasticity of substitution. The respective cost functions are given by equations (3) and (4) in the main text. Cost minimisation yields the labour demand functions (5) 
and (6) in the main text as well as the capital $K_{s}$ demand function at the sectoral level:

$$
K_{s}=Y_{s}\left(\frac{c_{v a, s}}{c_{h k, s}}\right)^{\sigma_{s}^{L}}\left(c_{h k, s} \frac{\bar{r}\left(1+\bar{t}_{k}\right)}{r\left(1+t_{k}\right)}\right)^{\sigma_{s}^{H}} .
$$

Capital and labour are mobile across sectors. The market for capital is perfectly competitive. In our central model variant, we assume that capital is internationally immobile, which reflects a short- to medium-run model horizon.

Each individual firm is assumed to be small in relation to its respective sector. All firms in one sector interact through monopolistic competition, i.e. they produce individual variants of the sectoral output good $Y_{s}$, which attract different consumers. This means that firms can exploit market power in their respective market segment. Producer output prices then consist of costs plus a fixed mark-up. The budget constraint of the representative firm reads

where

$$
\left(1-m_{s}\right) p_{y, s} Y_{s}=\sum_{s s} p_{a, s s} A_{s s, s}+r\left(1+t_{k}\right) K_{s}+\sum_{i} w_{i, s}\left(1+t_{l, i}\right) L_{i, s}
$$

$$
\begin{aligned}
m_{s} & :=\text { price mark-up rate } \\
p_{y, s} & :=\text { output price, } \\
A_{s s, s} & :=\text { intermediary input from Armington good } s s \\
p_{a, s} & :=\text { price of Armington good } s \\
L_{i, s} & :=\text { labour input of skill type } i .
\end{aligned}
$$

Profits in sector $s$ are given by

$$
\pi_{s}=m_{s} p_{y, s} Y_{s}
$$

\subsection{Private Households}

The household sector is differentiated into three representative households, two worker households and one capitalist household. One representative worker household captures the individual households with flexible labour supply that are part of the microsimulation module. The second representative worker household includes all households that are not part of the microsimulation module because their labour supply is assumed to be fixed. The third household is endowed with capital and property rights of the firms. It is also subject to a lump-sum tax or a transfer to balance the government's budget. 
Only the capitalist household takes a consumption-savings decision. The representation of this decision follows the approach of Ballard et al. (1985), where the savings function is sensitive to both the real interest rate and the price of investment goods. The households savings then correspond to the purchase of a uniform investment good at price $P_{I}$ per unit. This investment good is a fixed-coefficient composite of all Armington goods (see Section 1.3). The households derives its utility from the future stream of consumption that corresponds to the return to investment. In formal terms, the household's trade-off between current $Q$ and future consumption $C^{F}$ on the top level of its decision problem is

$$
\max U\left(Q, C^{F}\right) \quad \text { s.t. } \quad P_{Q} Q+P_{S} C^{F}=I_{e},
$$

where

$$
\begin{aligned}
& P_{Q}:=\text { price of } Q \\
& P_{S}:=\text { price of } C^{F} \\
& I_{e}:=\text { extended income, see (8). }
\end{aligned}
$$

To determine $P_{S}$, it is assumed that each unit of investment (savings), $S$, generates a stream of $\phi$ units of capital services in each future period (where $\phi$ is a constant determined by the steady state condition). These services yield yearly income at rate $r$ (net of taxes), which is then traded for the consumption goods composite at rate $P_{C}$ (note that $P_{C}$ is not differentiated across households, because all households are assumed to have the same consumption spending pattern). Together with the price $P_{I}$ of the investment good, which is defined as Leontief aggregate over Armington goods, we then obtain:

$$
P_{S}=\frac{P_{I} P_{C}}{\phi r}
$$

In calibrated share form, $U$ reads as

$$
U=\left[\theta^{Q}\left(\frac{Q}{\bar{Q}}\right)^{\frac{1-\sigma_{i}^{s}}{\sigma_{i}^{s}}}+\left(1-\theta^{Q}\right)\left(\frac{S}{\bar{S}}\right)^{\frac{1-\sigma_{i}^{s}}{\sigma_{i}^{s}}}\right]^{\frac{\sigma_{i}^{s}}{1-\sigma_{i}^{s}}}
$$

with $\theta^{Q}$ denoting the value share of current consumption in extended income. The associated unit expenditure function is

$$
P_{U}=\left[\theta^{Q}\left(\frac{P_{Q}}{\bar{P}_{Q}}\right)^{1-\sigma_{i}^{s}}+\left(1-\theta^{Q}\right)\left(\frac{P_{S}}{\bar{P}_{S}}\right)^{1-\sigma_{i}^{s}}\right]^{\frac{1}{1-\sigma_{i}^{s}}} .
$$


This yields the following savings demand function:

$$
S=\bar{S}\left(\frac{P_{U} \bar{P}_{S}}{\bar{P}_{U} P_{S}}\right)^{\sigma_{i}^{s}} \frac{I_{e} \bar{P}_{U}}{\bar{I}_{e} P_{U}} .
$$

The assumption of a flexible savings price drives a wedge between the amount of money actually spent on investment goods and the savings term appearing in the utility maximising problem, because $P_{S}$ generally does not equal $P_{I}$. In order to assure that the household's budget constraint actually holds, we must correct for the difference between $P_{S}$ and $P_{I}$. Extended income $I_{e}$ then becomes

$$
I_{e, i}=r \bar{K}+\Pi+\left(P_{S}-P_{I}\right) S-T_{L S}
$$

where

$$
\begin{aligned}
& \bar{K}:=\text { aggregated capital stock, } \\
& \Pi \quad:=\text { aggregated profits, } \\
& T_{L S}:=\text { lump-sum tax or benefit. }
\end{aligned}
$$

We assume identical consumption spending patterns for all three aggregate households. Aggregate consumption, $C$, which is is equal to the sum of the consumption of the three household types, is distributed among the different consumption goods, $C_{z}$, according to a CES function:

$$
\begin{gathered}
\frac{P_{C}}{\bar{P}_{C}}=\left[\sum_{z} \theta_{z}^{C}\left(\frac{p_{c, z}\left(1+t_{c, z}\right)}{\bar{p}_{c, z}\left(1+\bar{t}_{c, z}\right)}\right)^{1-\sigma_{c}}\right]^{\frac{1}{1-\sigma_{c}}}, \\
\frac{C_{z}}{\bar{C}_{z}}=\frac{C}{\bar{C}}\left(\frac{P_{C}}{\bar{P}_{C}} \frac{\bar{p}_{z, c}}{p_{z, c}}\right)^{\sigma_{c}}
\end{gathered}
$$

where

$$
\begin{aligned}
& P_{C}:=\text { consumer price index } \\
& \theta_{z}^{C}:=\text { benchmark value share of consumption good } z \\
& p_{c, z}:=\text { producer price of consumption good } z \\
& t_{c, z}:=\text { consumption tax } \\
& \sigma_{c}:=\text { elasticity of substitution in consumption. }
\end{aligned}
$$

Each consumption good, $C_{z}$, is composed of the Armington goods, $A_{s, z}$, (see Section 1.3) in fixed proportions:

$$
\frac{A_{s, z}}{\bar{A}_{s, z}}=\frac{C_{z}}{\bar{C}_{z}}
$$




\subsection{Foreign Trade}

Domestically produced goods are converted through a constant elasticity of transformation (CET) function into specific goods, $D_{s}$, destined for the domestic market and goods, $E x_{s}$, destined for the export market:

$$
\frac{Y_{s}}{\bar{Y}_{s}}=\left[\theta_{s}^{Y D}\left(\frac{D_{s}}{\bar{D}_{s}}\right)^{\frac{1+\eta}{\eta}}+\theta_{s}^{E x}\left(\frac{E x_{s}}{\overline{E x}_{s}}\right)^{\frac{1+\eta}{\eta}}\right]^{\frac{\eta}{1+\eta}},
$$

with an associated price equation

$$
\frac{p_{y, s}\left(1+t_{y, s}\right)}{\bar{p}_{y, s}\left(1+\bar{t}_{y, s}\right)}=\left[\theta_{s}^{Y D}\left(\frac{p_{d, s}}{\bar{p}_{d, s}}\right)^{1+\eta}+\theta_{s}^{E x}\left(\frac{x \cdot p_{E x, s}}{\bar{x} \cdot \bar{p}_{E x, s}}\right)^{1+\eta}\right]^{\frac{1}{1+\eta}}
$$

where

$$
\begin{array}{ll}
\theta_{s}^{Y D} & :=\text { value share of domestic consumption in domestic production, } \\
\theta_{s}^{E x} & :=\text { value share of exports, } \\
p_{d, s} & :=\text { price of } D_{s} \\
p_{E x, s} & :=\text { export prices, } \\
\eta & :=\text { elasticity of transformation, } \\
x & :=\text { foreign exchange rate. }
\end{array}
$$

Following the small open economy assumption, export and import prices in foreign currency are not affected by the behaviour of the domestic economy. In other words, the small open economy faces infinitely elastic world export demand and world import supply functions.

Analogously to the export side, we adopt the Armington assumption of product heterogeneity for the import side. A CES function characterises the choice between imported and domestically produced varieties of the same good:

$$
\begin{gathered}
\frac{A_{s}}{\bar{A}_{s}}=\left[\theta_{s}^{A D}\left(\frac{D_{s}}{\bar{D}_{s}}\right)^{\frac{1-\sigma_{s}^{I m}}{\sigma_{s}^{I m}}}+\theta_{s}^{A M}\left(\frac{I m_{s}}{\overline{I m}_{s}}\right)^{\frac{1-\sigma_{s}^{I m}}{\sigma_{s}^{I m}}}\right]^{\frac{\sigma_{s}^{I m}}{1-\sigma_{s}^{I m}}}, \\
\frac{p_{a, s}}{\bar{p}_{a, s}}=\left[\theta_{s}^{A D}\left(\frac{p_{d, s}}{\bar{p}_{d, s}}\right)^{1-\sigma_{s}^{I m}}+\theta_{s}^{A M}\left(\frac{x p_{I m, s}}{\bar{x} \bar{p}_{I m, s}}\right)^{1-\sigma_{s}^{I m}}\right]^{\frac{1}{1-\sigma_{s}^{I m}}},
\end{gathered}
$$

where 


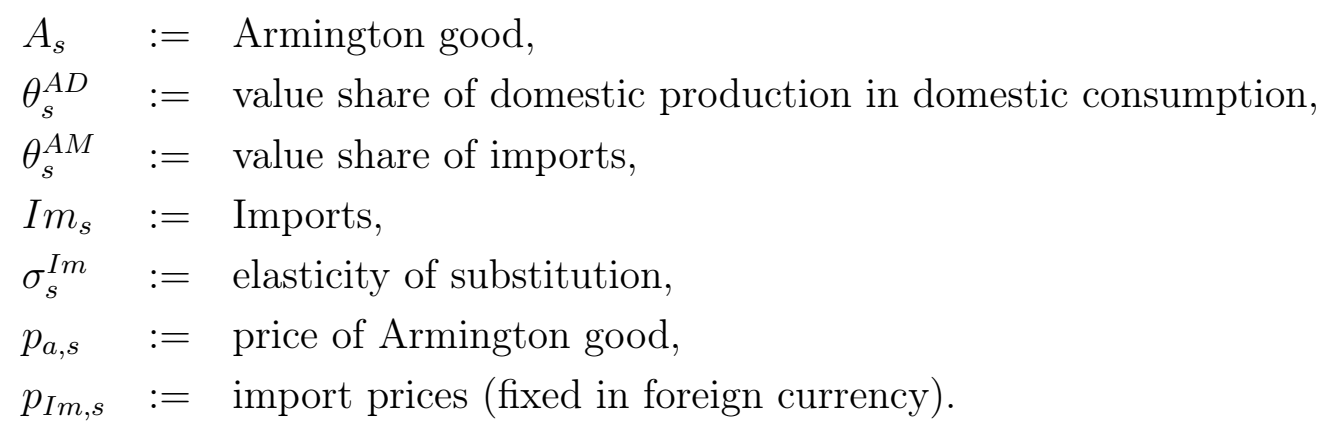

The Armington good enters intermediate and final demand. The associated market clearing condition is

$$
A_{s}=\sum_{z} A_{s, z}+G_{s}+I_{s}+\sum_{t} A_{s, t}
$$

where

$$
\begin{array}{ll}
A_{s, z}:=\text { derived Armington demand from private consumption, } \\
G_{s}:=\text { government consumption, } \\
I_{s}:=\text { investment demand, } \\
A_{s, s s}:=\text { intermediate demand from sector } s .
\end{array}
$$

The market clearing condition for the domestically produced good destined for the home market is

$$
\frac{Y_{s}}{\bar{Y}_{s}}\left(\frac{p_{y, s}\left(1+t_{y, s}\right)}{\bar{p}_{y, s}\left(1+\bar{t}_{y, s}\right)} \frac{\bar{p}_{d, s}}{p_{d, s}}\right)^{-\eta}=\frac{A}{\bar{A}}\left(\frac{p_{a, s}}{\bar{p}_{a, s}} \frac{\bar{p}_{d, s}}{p_{d, s}}\right)^{\sigma_{s}^{m}}
$$

Foreign closure of the model is warranted through the balance of payments constraint:

$$
\overline{B O P}+\sum_{s} \overline{E x}_{s} \frac{Y_{s}}{\bar{Y}_{s}}\left(\frac{p_{y, s}\left(1+t_{y, s}\right)}{\bar{p}_{y, s}\left(1+\bar{t}_{y, s}\right)} \frac{\bar{x}}{x}\right)^{-\eta}=\sum_{s} \bar{M}_{s} \frac{A}{\bar{A}}\left(\frac{p_{a}}{\bar{p}_{a}} \frac{\bar{x}\left(1+\bar{t}_{m, s}\right)}{x\left(1+t_{m, s}\right)}\right)^{\sigma_{s}^{m}} .
$$

The flexible exchange rate, $x$, adjusts so as to leave the benchmark balance of payments deficit (or surplus), $\overline{B O P}$, unchanged in terms of world market prices.

\section{Data and Parameterisation}

The remainder of this appendix lays out the parameterisation of our model:

- Cost shares of production factors and mark-up rates: Our main data source is the 2002 input-output table (IOT) provided by the Federal Statistical 
Office of Germany, which contains a consistent data set of economic transactions for 71 sectors. The German IOT provides a decomposition of total value-added into remuneration of capital and labour. We disaggregate the respective values into capital services and profits on the one hand, and labour incomes of the two skill groups on the other. To quantify profits, we use the German Federal Bank's (Bundesbank, 2006) publication on annual accounts of West-German enterprises. We take the profit per Euro of sales ratio (before tax) to measure profits. Expenses for capital services are calculated as the difference between total capital earnings and profits. Mark-up rates result as the ratio of profits over sales. To divide the total amount of labour earnings per sector into income of high-skilled and low-skilled workers, we employ data from the employment statistics register (Beschäftigtenstatistik). This database covers all employees holding a regular job, i.e. those who have to pay social security contributions. An employee without a vocational or academic degree is treated as "unskilled".

- Elasticity of substitution in production: Falk and Koebel (1997) provide estimates for five aggregated sectors. Complementary information on factor price elasticities are taken from Buslei and Steiner (1999).

- Calibration of the elasticities of substitution between current and future consumption $\sigma^{s}$ : $\sigma^{s}$ can be inferred from empirical estimates of the uncompensated elasticity of savings with respect to the interest rate, $\psi$. Using the demand equations of Section 1.2, the following relationship applies (index $i$ has been dropped): $\psi=\sigma^{s} \theta^{H}+\frac{r K}{I_{e}}$, where $\theta^{H}$ is the value share of savings and current utility. We set the elasticity of savings with respect to the interest rate equal to 0.4 (see Bernheim 2001).

- Income tax rate: We model a dual income tax, which treats incomes from different sources differently. To determine the average tax burden on capital, we sum up the revenue of the interest tax and the non-assessed income tax and add a small part of the assessed income tax according to information given by federal authorities (BMF, 2002).

- Profit tax rate: All other taxes levied on companies are treated as a profit tax. They include the corporate tax and parts of personal income taxation. We derive the tax rates applied at the aggregate level from the tax revenue statistics of the Federal Ministry of Finance (BMF, 2002). 
- Separation rates: These are computed from the IAB-Employee sample (IABS), which is a two per cent sample of the complete employment statistics register data. They are defined as outflows into unemployment (defined as outflows into transfer receipt) within one year over the number of employees in the middle of the same year. For the numerical simulations, we take a 5-year average (1997-2001).

- Armington elasticities: These are taken from Welsch (2001). They range between 0 and 2 . Services and the construction sector are treated as nontradables.

- The elasticity of transformation between domestically supplied and exported goods: It is uniformly set to 2 .

\section{References}

[1] Ballard, Charles L., Don Fullerton, John B. Shoven and John Whalley (1985): A General Equilibrium Model for Tax Policy Evaluation; The University of Chicago Press; National Bureau of Economic Research

[2] Bernheim, Douglas B. (1999): Taxation and Saving, NBER Working Paper 7061

[3] BMF (2002): Kassenmäßige Steuereinnahmen nach Steuereinnahmen nach Steuerarten in den Kalenderjahren 2002-2005

[4] Bundesbank (2006): Extrapolated Results from Financial Statements of German Enterprises 1994 to 2003

[5] Buslei, Hermann, and Viktor Steiner (1999): Beschaeftigungseffekte von Lohnsubventionen im Niedriglohnbereich, Baden-Baden: Nomos

[6] Falk, Martin, and Bertrand Koebel (1997): The Demand of Heterogeneous Labour in Germany, ZEW Discussion Paper 97-28, Mannheim

[7] Welsch, Heinz (2001): Armington Elasticities and Product Diversity in the European Community: A Comparative Assessment of Four Countries, Working Paper, University of Oldenburg 